\title{
Targeting Glycans and Heavily Glycosylated Proteins for Tumor Imaging
}

\author{
Ruben D. Houvast ${ }^{1}\left(\mathbb{D}\right.$, Mireille Vankemmelbeke ${ }^{2}$, Lindy G. Durrant ${ }^{2,3}$, Manfred Wuhrer ${ }^{4}(\mathbb{D}$, \\ Victor M. Baart ${ }^{1}$, Peter J. K. Kuppen ${ }^{1}{ }^{\circledR}$, Lioe-Fee de Geus-Oei ${ }^{5,6}$, Alexander L. Vahrmeijer ${ }^{1}$ \\ and Cornelis F. M. Sier $1,7, *$ (i)
}

1 Department of Surgery, Leiden University Medical Center, 2333 ZA Leiden, The Netherlands; R.D.Houvast@lumc.nl (R.D.H.); V.M.baart@lumc.nl (V.M.B.); P.J.K.Kuppen@lumc.nl (P.J.K.K.); A.L.vahrmeijer@lumc.nl (A.L.V.)

2 Scancell Limited, University of Nottingham Biodiscovery Institute, University Park, Nottingham NG7 2RD, UK; MireilleVankemmelbeke@scancell.co.uk (M.V.); Lindy.Durrant@nottingham.ac.uk (L.G.D.)

3 Division of Cancer and Stem Cells, School of Medicine, University of Nottingham Biodiscovery Institute, University Park, Nottingham NG7 2RD, UK

4 Center for Proteomics and Metabolomics, Leiden University Medical Center, 2333 ZA Leiden, The Netherlands; m.wuhrer@lumc.nl

5 Department of Radiology, Section of Nuclear Medicine, Leiden University Medical Center, 2333 ZA Leiden, The Netherlands; 1.f.de_geus-oei@lumc.nl

6 Biomedical Photonic Imaging Group, University of Twente, 7500 AE Enschede, The Netherlands

7 Percuros BV, 2333 ZA Leiden, The Netherlands

* Correspondence: c.f.m.sier@lumc.nl; Tel.: +31-752662610

Received: 9 November 2020; Accepted: 16 December 2020; Published: 21 December 2020

Simple Summary: Distinguishing malignancy from healthy tissue is essential for oncologic surgery. Targeted imaging during an operation aids the surgeon to operate better. The present tracers for detecting cancer are directed against proteins that are overexpressed on the membrane of tumor cells. This review evaluates the use of tumor-associated sugar molecules as an alternative for proteins to image cancer tissue. These sugar molecules are present as glycans on glycosylated membrane proteins and glycolipids. Due to their location and large numbers per cell, these sugar molecules might be better targets for tumor imaging than proteins.

\begin{abstract}
Real-time tumor imaging techniques are increasingly used in oncological surgery, but still need to be supplemented with novel targeted tracers, providing specific tumor tissue detection based on intra-tumoral processes or protein expression. To maximize tumor/non-tumor contrast, targets should be highly and homogenously expressed on tumor tissue only, preferably from the earliest developmental stage onward. Unfortunately, most evaluated tumor-associated proteins appear not to meet all of these criteria. Thus, the quest for ideal targets continues. Aberrant glycosylation of proteins and lipids is a fundamental hallmark of almost all cancer types and contributes to tumor progression. Additionally, overexpression of glycoproteins that carry aberrant glycans, such as mucins and proteoglycans, is observed. Selected tumor-associated glyco-antigens are abundantly expressed and could, thus, be ideal candidates for targeted tumor imaging. Nevertheless, glycan-based tumor imaging is still in its infancy. In this review, we highlight the potential of glycans, and heavily glycosylated proteoglycans and mucins as targets for multimodal tumor imaging by discussing the preclinical and clinical accomplishments within this field. Additionally, we describe the major advantages and limitations of targeting glycans compared to cancer-associated proteins. Lastly, by providing a brief overview of the most attractive tumor-associated glycans and glycosylated proteins in association with their respective tumor types, we set out the way for implementing glycan-based imaging in a clinical practice.
\end{abstract}


Keywords: cancer; aberrant glycosylation; carbohydrates; gangliosides; mucins; proteoglycans; molecular imaging; biomarkers

\section{Introduction}

Cancer is a leading cause of death worldwide, accompanied by a high burden on society. Biomedical imaging of malignant tissue plays a pivotal role in cancer detection, biopsy/therapeutic guidance, and monitoring, and, thus, is a major contributor in defining treatment and surgical planning [1]. Current imaging methodologies such as X-ray, ultrasound (US) computed tomography (CT), (functional) magnetic resonance imaging ((f)MRI), positron emission tomography (PET), and single-photon emission computed tomography (SPECT) are routinely applied within the standard of care before surgery takes place [1,2]. Untargeted techniques, such as X-ray, US, and CT, detect tissue irregularities based on anatomy and are, therefore, not exclusively specific for neoplastic tissue. Since tumor-targeted contrast agents provide a more specific indication of molecular processes in both premalignant lesions and tumors, their employment is of particular interest for preoperative staging, intraoperative detection, and postoperative monitoring of cancer.

An adequate tumor-to-background ratio (TBR), which allows a clear differentiation between healthy and malignant tissue, is the cornerstone of tumor imaging [3]. To maximize the TBR, an imaging target should be highly and homogenously expressed, ideally confined to tumor tissue only. Since the most available protein-based imaging targets appear to have limitations, such as substantial expression on normal surrounding tissues or lack of overexpression in early disease stages, the search for novel targets is an ever-continuing topic of research.

Aberrant glycosylation represents a hallmark of cancer, offering a set of novel tumor-specific targets [4]. In man, more than half of all membrane-bound or soluble, secreted proteins carry sugar molecules, referred to as glycans. These proteins are, therefore, categorized as glycosylated proteins or, in short, glycoproteins. Glycans can also be attached to lipids, forming glycolipid structures, such as gangliosides [5,6]. Of note, particular glycoproteins, such as proteoglycans and mucins, carry an extensive amount of glycans that account for the majority of their molecular weight and size, while extensively orchestrating their function. These glycoproteins are further referred to as heavily glycosylated proteins.

In cancer and other pathological process, including infection and chronic inflammation, glycans and heavily glycosylated proteins, which are intricately linked to disease progression, become overexpressed [7-10]. Despite the tumor-specific expression of these structures, only a few of these determinants have, so far, been validated as targets for tumor imaging. Table 1 summarizes the recent studies evaluating tumor-associated glycans and heavily glycosylated proteins as targets for molecular imaging of cancer and provides an overview of the most promising targets with respect to their tumor type. In this review, we provide a background on the most promising glycome targets and highlight the great potential of these structures as imaging targets by discussing the recent preclinical and clinical research into glycan-related tumor imaging. 
Table 1. An overview of recent imaging studies evaluating glycans and heavily glycosylated proteins.

\begin{tabular}{|c|c|c|c|c|c|c|c|}
\hline \multicolumn{8}{|c|}{ Preclinical Studies } \\
\hline Target & Targeting Moiety & Appl. & Conjugate & Cancer Type & Cell Line & Mouse Model or Phase & Reference \\
\hline \multirow[t]{3}{*}{ Thomsen-Friedenreich } & PNA-coated nano-beacon & FI & Coumarin 6 & Colon & HCT 116 & Subcutaneous & [11] \\
\hline & TF peptide & PET & ${ }^{64} \mathrm{Cu}-\mathrm{NO} 2 \mathrm{~A}$ & Breast & MDA-MB-435 & Subcutaneous & [12] \\
\hline & A38C tetramer & NIRF & AF647 & $\begin{array}{l}\text { Ovarian Peritoneal } \\
\text { Carcinomatosis }\end{array}$ & IGROV-1 & Orthotopic & [13] \\
\hline Thomsen-Nouveau & 2154F12A4 mAb & NIRF & Qdot-800 & Breast & MCF7 & Subcutaneous & [14] \\
\hline \multirow[t]{7}{*}{ sialyl-Thomsen-Nouveau } & $3 \mathrm{E} 8 \mathrm{scFv}$ & NIRF & IRDye 800 & Colon & LS174T & Orthotopic & [15] \\
\hline & $\begin{array}{c}\text { CC } 49 \mathrm{mAb} \\
\mathrm{HuCC} 49 \Delta \mathrm{C}_{\mathrm{H}} 2 \mathrm{mAb}\end{array}$ & NIRF & Су7 & Colon & LS174T & Subcutaneous & [16] \\
\hline & $\mathrm{HuCC} 49 \Delta \mathrm{C}_{\mathrm{H}} 2$ & PET & ${ }^{124} \mathrm{I}$-DOTA & Colon & LS174T & Subcutaneous & [17] \\
\hline & Pre-target: CC49-HaloTag & SPECT & ${ }^{111}$ In-HaloTag ligands & Colon & LS174T & Subcutaneous & [18] \\
\hline & $\mathrm{HuCC} 49 \Delta \mathrm{C}_{\mathrm{H}} 2$ & $\mathrm{SPECT} / \gamma$-scin & ${ }^{111} \mathrm{In}$ & Colon & LS174T & Subcutaneous & [19] \\
\hline & CC49 mAb-benzamide-TCO & $\mathrm{SPECT} / \gamma$-scin & ${ }^{111} \mathrm{In}-\mathrm{Tz}$ & Colon & LS174T & Subcutaneous & [20] \\
\hline & CC49 mAb-acetamide-TCO & SPECT $/ \gamma$-scin & ${ }^{111} \mathrm{In}-\mathrm{Tz}$ & Colon & LS174T & Subcutaneous & [21] \\
\hline Lewis $^{\mathrm{a} / \mathrm{c} / \mathrm{x}}$ & $\mathrm{CH} 88.2$ & NIRF & IRDye $800 \mathrm{CW}$ & Colon, Pancreas & HT-29, BxPC-3 & Subcutaneous & [22] \\
\hline \multirow[t]{9}{*}{ sialyl-Lewis ${ }^{\mathrm{a}}$} & Anti-CA19-9 mAb & FI & AF488 dye & Pancreas & BxPC-3 & $\begin{array}{l}\text { Subcutaneous, } \\
\text { orthotopic }\end{array}$ & [23] \\
\hline & Anti-CA 19-9 mAb & FI & DyLight 650 & Pancreas & PDOX & Orthotopic & [24] \\
\hline & Anti-CA19-9 diabody & PET & ${ }^{124} \mathrm{I}$ & Pancreas & $\begin{array}{l}\text { BxPc-3, Capan-2, } \\
\text { MIA PaCa-2 }\end{array}$ & Subcutaneous & [25] \\
\hline & Anti-CA19-9 cys- diabody & PET & ${ }^{124} \mathrm{I}$ & Pancreas & BxPC-3 & Subcutaneous & [26] \\
\hline & HuMAb-5B1 mAb & PET & ${ }^{89} \mathrm{Zr}-\mathrm{DFO} 123456$ & Bladder & HT 1197 & Subcutaneous & {$[27]$} \\
\hline & Pre-targeted: $5 \mathrm{~B} 1 \mathrm{mAb}$ & PET & ${ }^{89} \mathrm{Zr}$ & Pancreas & Capan-2 & $\begin{array}{l}\text { Subcutaneous, } \\
\text { orthotopic }\end{array}$ & [28] \\
\hline & 5B1 mAb-TCO & PET & ${ }^{64} \mathrm{Cu}-\mathrm{NOTA}-\mathrm{PEG} 7-\mathrm{Tz}$ & Pancreas & BxPC-3, Capan-2 & $\begin{array}{l}\text { Subcutaneous, } \\
\text { orthotopic }\end{array}$ & [29] \\
\hline & $\begin{array}{l}\text { PEGPH20 and } \\
\text { HuMab-5B1 mAb }\end{array}$ & PET & ${ }^{89} \mathrm{Zr}-\mathrm{DFO}$ & Pancreas & BxPC3-HAS3 & Subcutaneous & [30] \\
\hline & $5 \mathrm{~B} 1 \mathrm{mAb}$ & PET/NIRF & ${ }^{89} \mathrm{Zr}$-DFO FL dye & Pancreas & $\begin{array}{l}\text { BxPC-3, MIA } \\
\text { PaCa-2, Suit-2 }\end{array}$ & $\begin{array}{c}\text { Subcutaneous, } \\
\text { orthotopic }\end{array}$ & [31] \\
\hline sialyl-Lewis $^{x}$ & sLeX-carrying liposomes & NIRF & Cy5.5 & - & Ehrlich Ascites tumor & Subcutaneous & [32] \\
\hline \multirow[t]{2}{*}{ Lewis $^{y}$} & hu3S193 mAb & PET SPECT $/ \gamma$-scin & ${ }^{111} \mathrm{In},{ }^{86} \mathrm{Y}$ & Colon & HCT-15 & Subcutaneous & [33] \\
\hline & hu3S193 diabody $\mathrm{F}\left(\mathrm{ab}^{\prime}\right)_{2}$ & $\mathrm{SPECT} / \gamma$-scin & ${ }^{111}$ In-CHX-A"-DTPA & Breast & MCF-7 & Subcutaneous & [34] \\
\hline \multirow[t]{3}{*}{ GD2 } & ch14.18-CHO & NIRF & IRDye $800 \mathrm{CW}$ & Neuroblastoma & KCNR, patient-derived & Orthotopic & [35] \\
\hline & hu14.18K322A mAb & PET & ${ }^{64} \mathrm{Cu}-p$-NH2-Bn-DOTA & $\begin{array}{l}\text { Neuroblastoma, } \\
\text { melanoma }\end{array}$ & M21, PC-3. & Subcutaneous & [36] \\
\hline & hu14.18K322A mAb & PET & ${ }^{64} \mathrm{Cu}-\mathrm{Bn}-\mathrm{NOTA}$ & Osteosarcoma & SJOS072 & Subcutaneous & [37] \\
\hline
\end{tabular}


Table 1. Cont.

\begin{tabular}{|c|c|c|c|c|c|c|c|}
\hline \multicolumn{8}{|c|}{ Preclinical Studies } \\
\hline Target & Targeting Moiety & Appl. & Conjugate & Cancer Type & Cell Line & Mouse Model or Phase & Reference \\
\hline \multirow[t]{2}{*}{ Syndecan-1 } & Recombinant syndecan-1 & MSOT & CF750 succinyl ester & Pancreas & S2VP10 & Orthotopic & [38] \\
\hline & $9 \mathrm{E} 7.4 \mathrm{mAb}$ & PET & ${ }^{64} \mathrm{Cu}-\mathrm{TE} 2 \mathrm{~A}$ & Multiple myeloma & $5 \mathrm{~T} 33$ & $\begin{array}{c}\text { Subcutaneous, } \\
\text { orthotopic }\end{array}$ & [39] \\
\hline Glypican-1 & Glypican-1 mAb & FI/MRI & Gd-Au-nanoclusters & Pancreas & COLO-357 & Subcutaneous & [40] \\
\hline \multirow{4}{*}{ Glypican-3 } & Pretarget: L5 peptide & MRI & SA-PEG-USPIO & HCC & HepG2 & Subcutaneous & [41] \\
\hline & TJ12P1 peptide & NIRF & Су5.5 & HCC, Prostate & HepG2, PC3 & Subcutaneous & [42] \\
\hline & $\alpha \mathrm{GPC} 3 \mathrm{mAb}$ & PET & ${ }^{89} \mathrm{Zr}$ & HCC & HepG2 & Orthotopic & [43] \\
\hline & $\alpha \mathrm{GPC} 3 \mathrm{~F}\left(\mathrm{ab}^{\prime}\right)_{2}$ & PET & ${ }^{89} \mathrm{Zr}$ & HCC & HepG2 & Orthotopic & [44] \\
\hline \multirow[t]{12}{*}{ MUC1 } & EPPT peptide & MRI/NIRF & Magnetic NP-Cy5.5 & Colon & MC38 MUC1 & Orthotopic & [45] \\
\hline & EPPT peptide & MRI/NIRF & Magnetic NP-Cy5.5 & Breast & Spontaneous & Orthotopic & [46] \\
\hline & EPPT peptide & MRI/NIRF & Magnetic NP-Cy5.5 & Pancreas & Spontaneous & Orthotopic & [47] \\
\hline & EPPT peptide & MRI/NIRF & Magnetic NP-Cy5.5 & Colon & LS174T & Subcutaneous & [48] \\
\hline & $\mathrm{CT} 2 \mathrm{mAb}$ & NIRF & DyLight 650 & Pancreas & Panc-1, BxPC-3 & $\begin{array}{l}\text { Subcutaneous, } \\
\text { orthotopic }\end{array}$ & [49] \\
\hline & hMUC1 mAb & NIRF & DyLight 755 & Pancreas & Capan-2 & Subcutaneous & [50] \\
\hline & $\mathrm{CD} 227 \mathrm{mAb}$ & NIRF & Fluorescein-Су5.5 & Ovary & OVCAR3 & Subcutaneous & [51] \\
\hline & MUC1 aptamer & NIRF & MPA-PEG & Breast, liver & MCF-7, HepG2 & Subcutaneous & [52] \\
\hline & TAB 004 mAb & NIRF & ICG & Breast & PyMT, MMT, spontaneous & Orthotopic & [53] \\
\hline & GGSK-1/30 & PET/MRI & ${ }^{89} \mathrm{Zr}$ & Breast & PyMTxhuMUC1 & Subcutaneous & [54] \\
\hline & PR81 mAb & PET/SPECT & ${ }^{64} \mathrm{Cu}$-DOTA & Breast & MCF-7 & Subcutaneous & [55] \\
\hline & PR81 mAb & $\mathrm{SPECT} / \gamma$-scin & ${ }^{99 \mathrm{~m}} \mathrm{Tc}$ & Breast & Spontaneous & Orthotopic & [56] \\
\hline \multirow[t]{3}{*}{ MUC1/MUC5AC } & $\begin{array}{l}\text { Pretarget: TF10 } \\
\text { bispecific } \mathrm{mAb}\end{array}$ & $\gamma$-scin & ${ }^{125} \mathrm{I}-\mathrm{IMP}-288$ & Pancreas & Capan-1 & Subcutaneous & {$[57]$} \\
\hline & bsPAM4 F(ab') $)_{2}$ & $\gamma$-scin & ${ }^{125} \mathrm{I}$ & Pancreas & Capan-1 & Subcutaneous & [58] \\
\hline & Pretarget: bsPAM4 $\mathrm{F}\left(\mathrm{ab}^{\prime}\right)_{2}$ & $\gamma$-scin & $\begin{array}{l}{ }^{111} \text { In-IMP-156 } \\
\text { 99m Tc-IMP-192 }\end{array}$ & Pancreas & Capan-1 & Subcutaneous & [58] \\
\hline MUC5AC & $60 \mathrm{C}$ peptide & MRI & USPIO & Colon & HT-29, НCТ 116 & Subcutaneous & [59] \\
\hline \multirow[t]{4}{*}{ MUC16 } & AR9.6 mAb & NIRF & IRDye $800 C W$ & Pancreas & COLO 357, T3M4 & $\begin{array}{c}\text { Subcutaneous, } \\
\text { orthotopic }\end{array}$ & [60] \\
\hline & B43.13 mAb B43.13 scFv & PET & ${ }^{64} \mathrm{Cu}$ & Ovary & OVCAR3, SKOV3 & Subcutaneous & [61] \\
\hline & B43.13 mAb & PET & ${ }^{89} \mathrm{Zr}$ & Ovary & OVCAR3, SKOV3 & Subcutaneous & [62] \\
\hline & B43.13 mAb B43.13 scFv & PET & ${ }^{18} \mathrm{~F}(\mathrm{FBz})$ & Ovary & OVCAR3, SKOV3 & Subcutaneous & [63] \\
\hline
\end{tabular}


Table 1. Cont.

\begin{tabular}{|c|c|c|c|c|c|c|c|}
\hline \multicolumn{8}{|c|}{ Preclinical Studies } \\
\hline Target & Targeting Moiety & Appl. & Conjugate & Cancer Type & Cell Line & Mouse Model or Phase & Reference \\
\hline \multicolumn{8}{|c|}{ Clinical Studies } \\
\hline \multirow[t]{5}{*}{ sialyl-Thomsen-Nouveau } & $\mathrm{B} 72.3 \mathrm{mAb}$ & RIGS & ${ }^{125} \mathrm{I}$ & Colon, rectum & - & Phase $1 / 2$ & [64] \\
\hline & $\mathrm{CC} 49 \mathrm{mAb}$ & RIGS & ${ }^{125} \mathrm{I}$ & Colon, rectum & - & Phase 1 & [65] \\
\hline & CC49 mAb & RIGS & ${ }^{125} \mathrm{I}$ & Colon, rectum & - & Phase 1 & [66] \\
\hline & $\mathrm{HuCC} 49 \Delta \mathrm{C}_{\mathrm{H}} 2 \mathrm{mAb}$ & RIGS & ${ }^{125} \mathrm{I}$ & Colon, rectum & - & Phase 1 & [67] \\
\hline & $\mathrm{HuCC} 49 \Delta \mathrm{C}_{\mathrm{H}} 2 \mathrm{mAb}$ & RIGS & ${ }^{125} \mathrm{I}$ & Colon, rectum & - & Phase 1 & [68] \\
\hline \multirow[t]{2}{*}{ sialyl-Lewis $^{\mathrm{a}}$} & HuMAb-5B1 mAb & PET & ${ }^{89} \mathrm{Zr}-\mathrm{DFO}$ & Pancreas & - & Phase 1 & [69] \\
\hline & $\mathrm{B} 3 \mathrm{mAb}$ & SPECT & ${ }^{111}$ In & Various & - & Phase 1 & [70] \\
\hline Lewis $^{\mathrm{y}}$ & hu3S193 mAb & $\mathrm{SPECT} / \gamma$-scin & ${ }^{111}$ In & Lung & - & Phase 1 & [71] \\
\hline \multirow[t]{3}{*}{ GD2 } & ch14.18 mAb & $\gamma$-scin & ${ }^{99 \mathrm{~m}} \mathrm{Tc}$ & Neuroblastoma & - & Phase 1 & [72] \\
\hline & $3 \mathrm{~F} 8 \mathrm{mAb}$ & $\gamma$-scin & ${ }^{131} \mathrm{I}$ & Neuroblastoma & - & Phase 1 & [73] \\
\hline & $3 \mathrm{~F} 8 \mathrm{mAb}$ & PET & ${ }^{124} \mathrm{I}$ & Neuroblastoma & - & Case report & [74] \\
\hline \multirow[t]{2}{*}{ MUC1 } & $\mathrm{C} 595 \mathrm{mAb}$ & $\gamma$-scin & ${ }^{111}$ In & Bladder & - & Phase 1 & [75] \\
\hline & $\mathrm{C} 595 \mathrm{mAb}$ & $\gamma$-scin & ${ }^{99 \mathrm{~m}} \mathrm{Tc}$ & Bladder & - & Phase 1 & [76] \\
\hline MUC1/MUC5AC & hPAM4 mAb & $\gamma$-scin & ${ }^{111}$ In & Pancreas & - & Phase 1 & [77] \\
\hline
\end{tabular}

Abbreviations: Appl.: application, CHX-A"-DTPA: C-functionalized Trans-cyclohexyl Diethylenetriaminepentaacetic acid, $\gamma$-scin: Gamma Scintigraphy, DFO: Desferrioxamine, DOTA: 1, 4,

7, 10-Tetraazacyclododecane-1, 4, 7, 10-Tetra-Acetic Acid, GSG: Gly-Ser-Gly, FI: Fluorescence Imaging, HCC: Hepatocellular Carcinoma, ICG: Indocyanine Green, PEG: Polyethylene Glycol,

MAb: Monoclonal Antibody, MSOT: Multispectral Optoacoustic Imaging, MRI: Magnetic Resonance Imaging, NIRF: Near-Infrared Fluorescence, NP: Nanoparticle NOTA: 1, 4,

7-Triazacyclononane-1, 4, 7-Triacetic Acid, NO2A: 1, 4, 7-Triazacyclononane-1, 4-Diacetate, PDOX: Patient-Derived Orthotopic Xenograft, PNA: Arachis Hypogaea Agglutinin, RIGS: radioimmunoguided surgery, SA: Streptavidin, TCO: Trans-Cyclooctene, Tz: Tetrazine, USPIO: Ultrasmall Superparamagnetic Iron Oxide. 


\section{Glycans}

\subsection{Background}

The attachment of glycans to proteins occurs mainly in two forms, namely $\mathrm{O}$-and $\mathrm{N}$-linked. O-linked glycosylation occurs via the attachment of a sugar molecule to the hydroxyl group of mainly serine (Ser) or threonine (Thr) residue side chains in a protein, whereas $N$-linked glycosylation occurs via the attachment of an oligosaccharide consisting of multiple sugar molecules to the nitrogen atom of asparagine (Asn) side chains (Figure 1a,b) [78]. N-glycans, which all share a common glycan core, can be grouped into high-mannose, hybrid, and complex $N$-glycan structures, as depicted in Figure 1a. However, since the development of $N$-glycan-specific targeting vehicles is challenging due to the extensive structural similarity of $N$-glycans, therapeutic and imaging tracer development generally focusses on O-linked glycans (explained in detail in Section 6: Targeting the Glycome: Opportunities and Challenges).

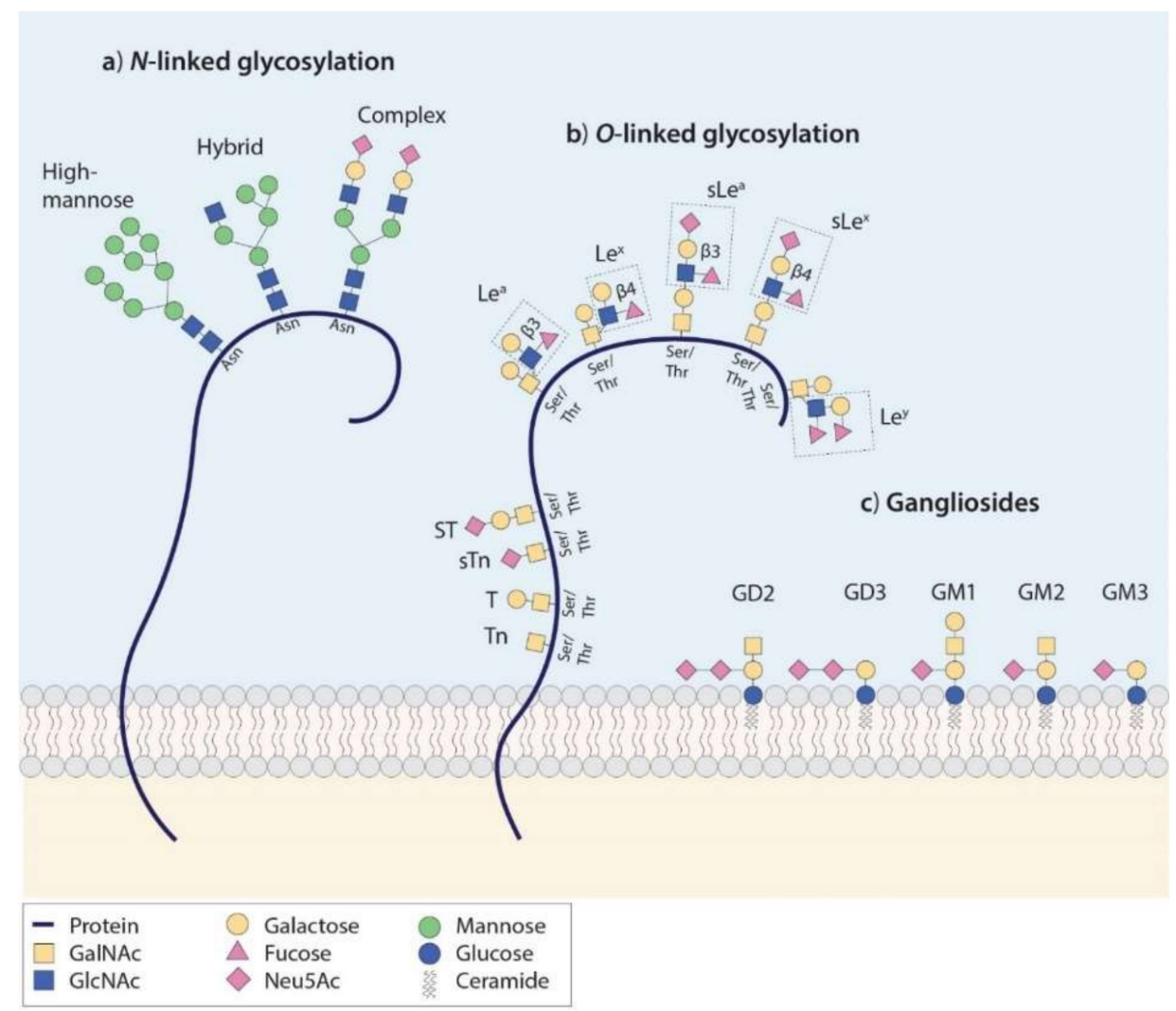

Figure 1. Schematic structures of oligosaccharides: (a) N-Linked glycans are covalently attached to proteins via asparagine (Asn). $\mathrm{N}$-Glycans are assigned to three groups in which all share the same Pentasaccharide, Trimannosyl core structure: (1) High-Mannose N-glycans (2) Hybrid N-glycans in which the core is extended via both mannose and $N$-Acetylglucosamine (GlcNAc) residues and (3) complex $N$-glycans in which GlcNAc-initiated antennae are present. (b) O-linked glycans are covalently attached to proteins via Serine (Ser) or Threonine (Thr). Mucin-type O-Glycans are initiated by N-Acetylgalactosamine (GalNAc), while elongated, GlcNAc-containing glycans (displayed in dashed boxes) contribute to Type 1 (Gal $\beta 1,3 \mathrm{GlcNAc}$ ) and Type 2 (Gal $\beta 1,4 \mathrm{GlcNAc}$ ) structures. In this figure, sLe ${ }^{\mathrm{a}}$ and $\mathrm{sLe}^{\mathrm{x}}$ extend from a core 1 structure (Galß1-3GalNAc), while $\mathrm{Le}^{\mathrm{a}}$, Le ${ }^{\mathrm{x}}$, and Le $\mathrm{Le}^{\mathrm{y}}$ are attached to a core 2 structure (Gal $\beta 1,3[\beta 1,61 \mathrm{cNAc}]$ GalNAc). Both $N$-and $O$-glycan antigens can carry $\mathrm{N}$-Acetylneuraminic (Neu5Ac) acids, categorizing these structures as sialylated antigens. (c) Gangliosides consist of varying arrangement of sialic acid-containing glycan chain attached to the cell membrane via a lipid anchor, the ceramide. GM1 to GM3 are initiated by glucose and carry one sialic acid, while GD2 and GD3 carry two sialic acids. 
The most abundant form of O-glycosylation is mucin-type (GalNAc) O-glycosylation in which extracellular or secreted glycoproteins are modified with $\mathrm{N}$-acetylgalactosamine residues (GalNAc-alpha-O-Ser/Thr) that, by the addition of Galactose and N-acetylglucosamine (GlcNAc) residues, constitute different $\mathrm{O}$-GalNAc core structures. $\mathrm{O}$-glycan cores can be further elongated by the addition of additional monosaccharides, which results in specific terminal glycan motifs, of which some are shown in Figure 1b. These structures play roles in biological processes such as cell adhesion, receptor activation, cell growth, signal transduction, apoptosis, and endocytosis and may confer antigenicity or provide cell protection by contributing to the glycocalyx formation [79-81].

\subsection{Aberrant Glycosylation in Cancer}

In cancer, aberrant glycosylation is mainly characterized by increased $\mathrm{N}$-glycan branching, augmented $O$-glycan density, incomplete glycan synthesis, and, in more advanced cancers, synthesis of neo-glycan determinants that carry large amounts of sialic acids or fucose residues [10-82]. This leads to the appearance of immature truncated GalNAc/mucin-type O-glycans, such as sialyl-Thomsen-nouveau (sTn) and complex versions of Lewis glycans, such as sialyl-di-Lewis ${ }^{\mathrm{a}}$ (s-di-Le ${ }^{\mathrm{a}}$ ) [83]. In addition, overexpression of normally expressed Lewis glycan antigens, such as sialyl-Lewis ${ }^{\mathrm{a}}\left(\right.$ sLe $^{\mathrm{a}}$, known as CA19-9) and its structural isomer sialyl-Lewis ${ }^{\mathrm{x}}\left(\mathrm{sLe}^{\mathrm{x}}\right)$ is observed. sTn, its non-sialylated counterpart $\mathrm{Tn}$, and Lewis glycans are extensively expressed in a wide variety of epithelial-derived cancers $[9,84]$ such as cancers of the digestive tract [8,85-87], breast [86,88-90], lung [86,91,92], bladder [86,90,93], and ovaries $[86,87,94]$. Figure $1 \mathrm{~b}$ depicts the schematic structure of these and other tumor-associated $O$-glycoantigens and illustrates the most frequently observed $O$-GalNAc core structures from which they extend.

Tumor-associated glycans are heavily involved in tumor progression both directly or indirectly by influencing its protein or lipid carrier's function [95]. For instance, both sLe ${ }^{\mathrm{x}}$ and $\mathrm{sLe}^{\mathrm{a}}$ can serve as ligands for E-selectins and P-selectins present on endothelial cells, thereby facilitating cell adhesion, extravasation, and metastasis [85]. $\mathrm{sLe}^{\mathrm{a}}$ is overexpressed on a wide variety of tumor-associated glycoproteins, including mucin-1 (MUC1), MUC5AC, and MUC16 (CA125) [96,97]. Moreover, sLe ${ }^{\mathrm{x}}$, also called CD15s, is overexpressed on liver acute-phase proteins, including haptoglobin [98] and ceruloplasmin [99] and on mucins MUC1, MUC5AC, and MUC6 in pancreatic cancer [97-100]. This suggests a major advantage of targeting glycans in relation to protein targeting, as multiple tumor-associated proteins can be targeted simultaneously via a single glycan motif (described in detail in Section 6: Targeting the Glycome: Opportunities and Challenges). Moreover, glycans are, in relation to proteins, very densely distributed on the outermost layer of the cell membrane [101], making them easily accessible for targeting vehicles and, consequently, attractive targets for imaging.

\subsection{Imaging of $s T n$}

Despite its abundant expression in a wide variety of carcinomas, e.g., lung, ovarian, bladder, breast, and almost all gastrointestinal cancers with low normal tissue distribution (reviewed in Reference [84]). Studies into sTn-targeted molecular imaging have particularly focused on colorectal tumors and reported clear tumor delineation. sTn, which is overexpressed on mucins MUC1 [102,103], MUC2 [97], MUC5AC [97], and MUC6 [97], and oncoprotein CD44(v6) [103,104], has been evaluated as a target in several imaging studies aiming to optimize a SPECT imaging contrast in colorectal cancer. For instance, Rossin et al. described a strategy using anti-sTn monoclonal antibody $(\mathrm{mAb}) \mathrm{CC} 49$ to pre-target tumor cells prior to administration of two mAb-clearing agents followed by administration of the CC49-binding radiolabel. Pre-targeting could theoretically provide higher tumor-to-background contrast by clearing unbound CC49 mAbs from the circulation [20]. LS174T colon carcinoma-carrying mice that were administered with clearing agents showed a remarkable 125-fold improvement of the tumor-to-blood ratio $3 \mathrm{~h}$ post-injection, when compared to administration of (non-pre-targeted) ${ }^{177} \mathrm{Lu}-\mathrm{NOTA}-\mathrm{CC} 49$.

Apart from SPECT imaging, sTn has been evaluated as a target for real-time intra-operative imaging using near-infrared fluorescent (NIRF) light. For instance, murine CC49 and its humanized, 
$\mathrm{CH} 2$-deleted variant $\mathrm{HuCC} 49 \Delta \mathrm{C}_{\mathrm{H}}$ 2, were conjugated to NIR dye Cy7 and evaluated for NIRF imaging in a subcutaneous mouse model of colorectal cancer [16]. Administration of murine CC49-Cy7 allowed clear tumor visualization with a tumor-to-blood ratio of 15.5 at $96 \mathrm{~h}$ post-injection. Even though its humanized counterpart was cleared roughly twice as fast, it showed a tumor-to-blood ratio of 12.0 at $18 \mathrm{~h}$ post-injection with a low specific uptake in other organs, confirming the great potential of sTn as a target for imaging of colorectal tumors. However, since Cy7 has not been clinically approved, the translational potential of the CC49-Cy7 tracer in this confirmation is currently limited. Apart from NIRF imaging, the same research group conjugated $\mathrm{HuCC} 49 \Delta \mathrm{C}_{\mathrm{H}} 2$ to ${ }^{124} \mathrm{I}$ and showed excellent tumor delineation using PET imaging in the same mouse model [17].

The low immunogenicity of glycans has both challenged therapeutic efficacy as well as the development of specific and high-affinity IgG mAbs (described in detail in Section 6: Targeting the Glycome: Opportunities and Challenges) $[105,106]$. For instance, sTn antibodies have been shown to additionally react with the non-sialylated Tn epitope and binding to sTn that was dependent on the glycoprotein it was expressed on. Thus, the need for novel antibodies that could serve as a sTn-targeting moiety arose [86,107]. For example, Loureiro et al. developed and characterized the novel sTn mAb L2A5, which showed tumor-specific reactivity with all included bladder and colorectal cancer tissues, and $20 \%$ of triple-negative breast cancer tissues [90]. Moreover, Prendergast et al. developed a panel of murine, high-affinity, internalizing sTn antibodies that showed positive immunohistochemical staining of the majority of human ovarian, bladder, colorectal, pancreatic, lung, and gastric tumor tissues, with low reactivity to normal human tissues [86]. Two mAbs, 5G2-1B3 and 2G12-2B2, were subsequently humanized, whilst maintaining limited reactivity with normal human tissues. Of these mAbs, 2G12-2B2-MMAE showed effective tumor targeting by inhibiting tumor growth in both an ovarian cancer cell line and patient-derived ovarian xenograft mouse models [87]. Thus, sTn, although underexplored, may pose a very suitable target considering its potential employment for imaging of a wide range of tumor types [84].

\subsection{Imaging of $s L e^{a} / C A 19-9$}

Considering its clinically applied tumor-specific upregulation in tissues and sera of pancreatic cancer patients, sLe /CA19-9 has been exploited as a target for imaging and therapy [23,25,26,28-31]. Houghton et al. have used the humanized mAb 5B1 conjugated to a NIRF dye and radionuclide ${ }^{89} \mathrm{Zr}$ [108] for bimodal fluorescence/PET imaging of pancreatic tumors, resulting in an excellent tumor, a positive lymph node, and metastases localization in both a subcutaneous and orthotopic metastasizing mouse model [31]. To improve tumor/non-tumor contrast even further, several studies using anti-sLe ${ }^{a}$ mAbs to pre-target tumor cells before radiolabel administration have been developed, which have led to remarkable improvements in TBR via various techniques [28,29].

During malignant transformation, sLe ${ }^{a}$ but also $\mathrm{sLe}^{\mathrm{x}}$, become expressed on the glycoprotein CEA (carcinoembryonic antigen) $[109,110]$, which is currently undergoing clinical translation facilitated by our group as a target for NIRF imaging of colorectal cancer (SGM-101, SurgiMab) [111]. Given their wide expression across different tumor types and multiple tumor-associated proteins, sLe ${ }^{\mathrm{a}}$ and $_{\mathrm{sLe}}{ }^{\mathrm{x}}$, may be very suitable candidates for pan-carcinoma tumor imaging.

Several mAbs recognizing alternative Lewis glycans have been developed and described. Noble et al. described the mAb 692/29, which recognizes a unique set of Lewis ${ }^{\mathrm{y}}$ and Lewis ${ }^{\mathrm{b}}$ glyco-epitopes. Despite some reactivity with normal gastrointestinal epithelia, 696/29, bound to $82 \%$ of colorectal tumors showed inhibition of cell growth in vivo that was further supplemented by chemotherapy [112]. More recently, the novel murine/chimeric IgG mAbs FG88.2 and FG129/CH129 were described, which were bound to Lewis ${ }^{\mathrm{a} / \mathrm{c} / \mathrm{x}}$-related and sialyl-di-Lewis ${ }^{\mathrm{a}}$ glyco-epitopes, respectively, that were highly expressed on pancreatic, colorectal, stomach, lung, and ovarian carcinomas with restricted expression in normal tissues $[83,113]$. Subsequently, our group evaluated IRDye 800CW-conjugated FG88.2 and its chimeric mouse/human counterpart, CH88.2, for real-time 
NIRF imaging in subcutaneous mouse models of colon and pancreatic cancer, which provided excellent tumor localization and delineation using a clinical camera system [22].

Lastly, Shimomura et al. described an alternative approach for glycan-targeting by using glycan-binding lectin rBC2LC-N, which binds to type 1 (Fuc $\alpha 1-2$ Gal $\beta 1-3 G l c N A c$ ) and type 3/4 fucosylated glycans (Fuc $\alpha 1-2$ Gal $\beta 1-3 G a l N A c$, see Figure 1a). This showed reactivity with almost all tested human pancreatic ductal adenocarcinoma (PDAC) specimens [114]. After conjugation with a bacterial exotoxin, a remarkable cytotoxicity was observed in several patient-derived models, suggesting excellent tumor penetration. Most importantly, the authors excluded that rBC2LC-N caused human serum agglutination in vitro, which is a frequently observed phenomenon after lectin administration [115]. These results not only pave the way for a potential imaging strategy for PDAC, but also provide a novel explorable approach for glycan targeting.

\subsection{Glycan Imaging in the Clinic}

Several glycan-targeting imaging tracers have already been evaluated in a clinical setting. For instance, anti-sTn mAb CC49 and its predecessor mAb B72.3 were conjugated to ${ }^{125} \mathrm{I}$ and used as a tracer for radio-immuno-guided surgery (RIGS) of colorectal cancer [64-68]. Intraoperatively, RIGS using ${ }^{125}$ I-CC 49 allowed detection of $86 \%$ and $97 \%$ of primary and recurrent tumors, respectively, while the surgical resection was influenced in roughly half of the cases [65]. However, routine clinical implementation of RIGS is limited by the inconveniently long period between tracer administration and surgery (one week) and handling of the long-lived ${ }^{125}$ I isotope, and, therefore, RIGS has been overtaken by other imaging strategies, such as NIRF imaging [116]. In addition, the anti-CA19.9 tracer ${ }^{89} \mathrm{Zr}$-DFO-HuMab-5B1 (MVT-2163) has recently been evaluated in a Phase I trial for PET imaging of pancreatic cancer and allowed high-contrast imaging of tumors and metastases, including lesions that were not detected with traditional imaging methods [69]. Administration of MVT-2163 was safe, causing mild to moderate side effects on the first day, including nausea, fever, and hypertension, in $50 \%$ of patients.

\section{Gangliosides}

\subsection{Background}

Gangliosides are sialic acid-containing glycosphingolipids (a glycolipid subclass) that are attached to the cell membrane via a lipid portion: the ceramide (Figure 1c). These structures are abundantly present in the central nervous system where they serve pivotal roles in its development and maintenance [117]. Simple ganglioside structures, such as GD2, GD3, or GM1-3, are aberrantly expressed in several neuroectodermal-derived cancers, including melanoma, osteosarcoma, and neuroblastoma, and in breast cancer [118-121]. Several studies have shown that gangliosides are involved in tumor cell proliferation, mobilization, and metastasis $[122,123]$.

In 2015, the human/mouse chimeric anti-GD2 mAb ch14.18 (dinutuximab) became the first and only FDA-approved therapeutic anti-glycan antibody. Administered in combination with IL-2, GM-CSF, and isotretinoin, dinutuximab increased by two-year event-free, and overall survival (OS) rates of high-risk neuroblastoma patients with $20 \%$ and $10.9 \%$, respectively $[124,125]$. Phase II and III dinutuximab trials in neuroblastoma (NCT02743429, NCT01704716), osteosarcoma (NCT02484443), and small cell lung cancer (NCT03098030) are underway.

\subsection{Imaging of $G D 2$}

Several studies have validated the humanized variant of dinutuximab, hu14.18, as a targeting moiety for tumor imaging. For instance, Vāvere et al. validated the hu14.18K322A variant of hu14.18, which was developed to decrease neuropathic pain after administration while maintaining cytotoxicity, as a targeting moiety for PET imaging. Administration of ${ }^{64} \mathrm{Cu}$-labeled hu14.18K322A to GD2-postive M21 melanoma xenograft-carrying mice allowed excellent tumor delineation and localization with low 
tracer uptake in other organs [36]. More recently, the same group additionally validated the tracer in a patient-derived and metastatic orthotopic in vivo model of osteosarcoma and observed similar tumor-specificity related to GD2 expression and detected tumor lesions as small as $29 \mathrm{~mm}^{3}$ at $48 \mathrm{~h}$ after injection [37]. Dinutuximab-beta (ch18.18/CHO), which is an FDA-approved biosimilar variant of ch14.18, was recently conjugated to IRDye 800CW and evaluated for NIRF imaging of neuroblastoma in a mouse model [35]. At four days post-injection, the tracer showed high-contrast tumor accumulation in both orthotopic transplanted human KCNR neuroblastoma cells and patient-derived organoid xenograft mouse models. Moreover, the authors showed that neoadjuvant anti-GD2 immunotherapy did not influence tracer uptake, supporting an application of the tracer in a clinical setting. Alternatively, Jiao et al. used gold nanoparticles (GNPs) conjugated to hu14.18K322A as NK-cell activators as well as CT contrast agents [126]. After incubating NB1691 neuroblastoma cells and M21 melanoma cells with the construct, the authors observed a two-fold higher antibody-dependent cellular cytotoxicity efficacy, along with a 5-fold to 8-fold increase in CT imaging contrast compared to controls, proposing a potent bimodal application of the tracer. None of the previously mentioned studies evaluated neurotoxicity following administration of anti-GD2 contrast agents' administration. Providing that imaging tracers are administrated in a substantially lower dose than therapeutic agents, one may expect that neurotoxicity will not pose a limiting factor for GD2-based imaging.

\subsection{Ganglioside-Based Nerve Imaging}

Although other gangliosides have been established as not specific for tumor cells, they might still be of use as targets for imaging during oncological surgery. For instance, to avoid nerve injury during prostatectomy, surgeons may be assisted by a real-time nerve monitoring system, based on a ganglioside specific NIRF tracer. Massaad et al. used the anti-GT1b-2b mAb, which has been shown to bind axons in spinal roots, peripheral nerves, and neurons of dorsal root ganglia and the spinal cord, as a targeting moiety [127]. Conjugated to fluorescent dye Dylight550, peripheral nerves could be imaged using the tracer from 24 hours up to 20 days after intravenous administration to wild-type mice. Furthermore, the authors reported that GT1b-2b-induced nerve fiber damage was not present.

\section{Proteoglycans}

\subsection{Background}

Heavily glycosylated proteins, such as proteoglycans, also form an interesting array of targets for tumor imaging, in addition to tumor-associated glycans Figure 2a. Proteoglycans (PGs) consist of linear polysaccharide chains (glycosaminoglycans, GAGs) that are covalently attached to a protein core. PGs form a major component of the extracellular matrix and contribute significantly to the structural integrity of tissues [128]. Moreover, PGs play multifaceted roles in the regulation of essential signaling pathways that are involved in cell proliferation, adhesion and migration, apoptosis, and angiogenesis [129]. Heparan sulfate proteoglycans (HSPGs), such as syndecans and glypicans, have gained significant scientific interest within the oncological field [130,131]. Syndecans and glypicans are localized at the cell surface, allowing them to be heavily involved in integrin and growth factor signaling and regulation of Wnt and Hedgehog signaling, which are pathways known to be dysregulated in cancer [132-135]. Many recent studies reported overexpression [131] and, understandably, great involvement of HSPGs in carcinogenesis and tumor progression in a wide range of tumors, making these structures potential targets for molecular imaging of cancer $[129,131,135-138]$. 


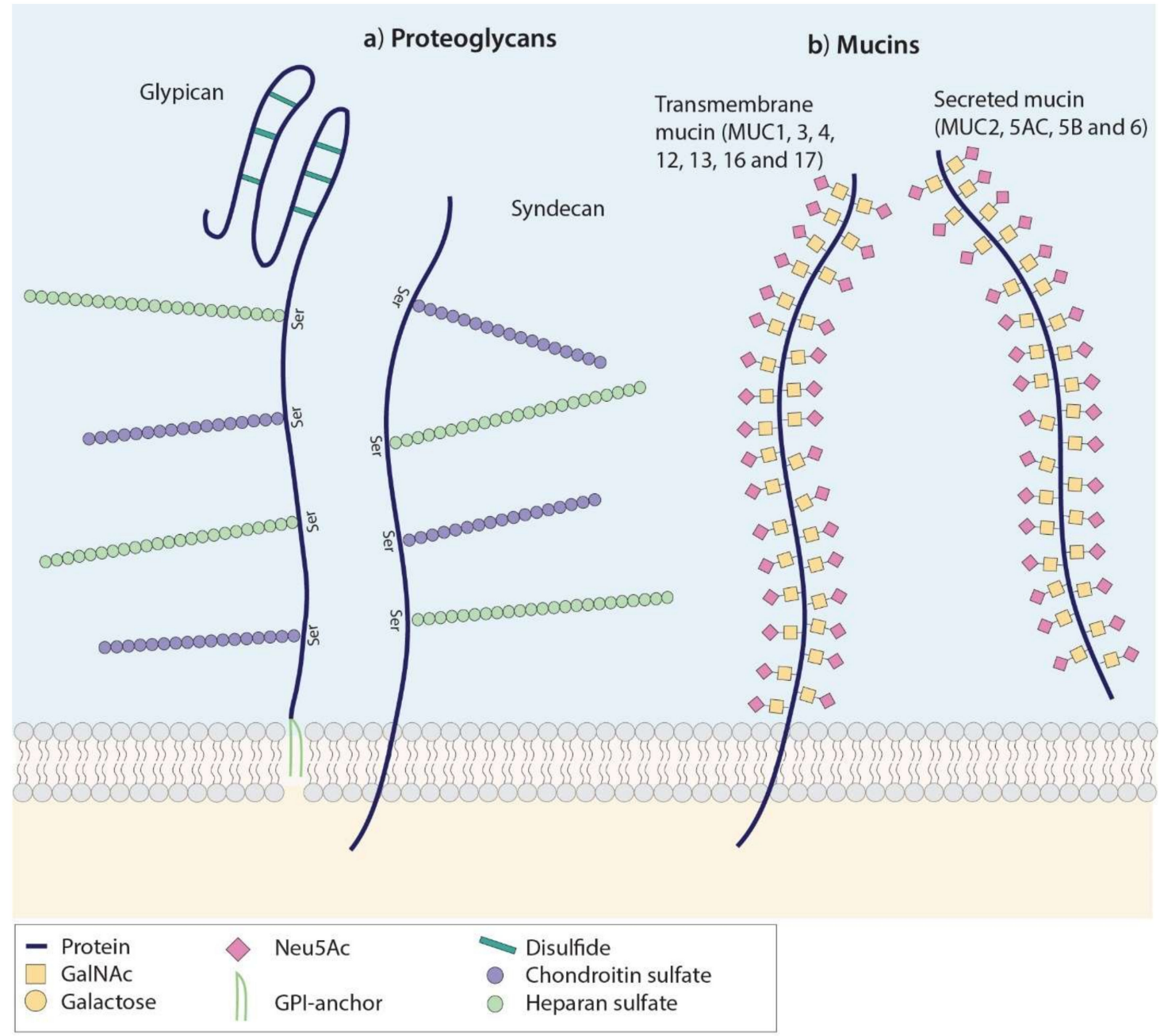

Figure 2. Schematic structure of heavily glycosylated glycoproteins. (a) Proteoglycans are transmembrane glycoproteins that consist of a core protein decorated with glycosaminoglycan (GAG) chains. In glypicans, the protein core is stabilized by disulphide bridges and linked to the cell membrane via GPI-anchors. Both glypicans and syndecans contain serine-linked heparin sulphate and chondroitin sulphate GAGs at both sides of the protein (here only depicted on one side), classifying them as HSPGs. (b) Mucins are high-molecular weight proteins that are extensively decorated with mucin-type O-Glycans, schematically illustrated here by the sTn epitope. Mucins are subdivided into transmembrane (MUC1, MUC3, MUC4, MUC12, MUC13, MUC16, and MUC17) and secreted mucins (MUC2, MUC5AC, MUC5B, and MUC6).

\subsection{Imaging of Syndecan-1}

Syndecan-1 (CD138) was evaluated as a target for bimodal NIRF imaging and multispectral optoacoustic tomography (MSOT, also known as photoacoustic imaging) in an orthotopic in vivo model of pancreatic cancer [38]. At $6 \mathrm{~h}$ post-injection, the fluorescent tumor signal was undetectable, while MSOT provided a clear high-contrast imaging of tumor location with inferior liver and kidney uptake. Taken together, these results underline both the advantage of MSOT imaging in relation to NIRF imaging, i.e., deeper imaging depth as well as the great potential of this syndecan-1 tracer for combined MSOT/NIR imaging of a wide arrange of tumors, given the broad tumor expression of syndecan-1 [138].

More recently, Bailly et al. compared the mAb-based syndecan- 1 tracer ${ }^{64} \mathrm{Cu}$-TE2A-9E7.4 with the conventional tracer ${ }^{18} \mathrm{~F}-\mathrm{FDG}$ and ${ }^{64} \mathrm{CuCl}_{2}$ for PET imaging of primary multiple myeloma lesions and metastases using a syngeneic mouse model [39]. Although ${ }^{64} \mathrm{Cu}-\mathrm{TE} 2 \mathrm{~A}-9 \mathrm{E} 7.4$ was found to accumulate 
in the liver, spleen, kidneys, and digestive tract, the tracer outperformed both ${ }^{18} \mathrm{~F}-\mathrm{FDG}$ and ${ }^{64} \mathrm{CuCl}_{2}$ in terms of non-tumor uptake and tumor-to-blood contrast (41 at $24 \mathrm{~h}$ post-injection). Moreover, the tracer allowed high-contrast imaging of most metastatic depositions of which one was not observed using ${ }^{18}$ F-FDG.

\subsection{Imaging of Glypican-3}

Glypican-3 is a highly sensitive biomarker of hepatocellular carcinoma (HCC) $[139,140]$. Over 70\% of HCC cases express high levels of glypican-3, while expression is absent on benign hepatic lesions and normal liver tissue $[136,140,141]$. A vast number of studies evaluated glypican-3 as a PET, ultrasound (US), NIR, and MR imaging target for HCC using several targeting moieties and conjugates of a different origin [40-44,142]. In all in vivo studies, HepG2 cells could be clearly localized and delineated using a glypican-3-specific tracer. Meanwhile, glypican-3 is validated as a target for immunotherapy of HCC in various phase I trials, paving the way for a potential combined therapeutic/imaging application [143].

\section{Mucins}

\subsection{Background}

Mucins form another class of high molecular weight proteins heavily glycosylated with truncated $\mathrm{O}$-glycans (Figure 2b) [144]. These often negatively charged sugar branches on both transmembrane (MUC1, MUC4, MUC13, and MUC16) and secreted mucins (MUC2, MUC5AC, MUC5B, and MUC6) form a physical barrier, protecting the underlying epithelium [144-146]. In cancer, aberrantly glycosylated mucins become overexpressed and are, directly or indirectly via their truncated sTn/Tn/TF (Thomsen-Friedenreich) glyco-epitopes, heavily involved in proliferation, migration, invasion, metastasis, and chemo-resistance, and radio-resistance of tumor cells [147-152]. For instance, both MUC1, also called epithelial membrane antigen (EMA), and MUC16, also called CA125, are overexpressed in a wide variety of cancer types, including breast [153], lung [154,155], gastrointestinal [146,151,156,157], head-and-neck [158,159], ovarian [160,161], and other gynecological malignancies [162,163], making them potential targets for pan-carcinoma imaging.

\subsection{Imaging of $M U C 1$}

Several preclinical studies described MUC1 as a promising target for molecular imaging $[45-53,55]$. For instance, Chen et al. evaluated MUC1-specific aptamers, conjugated to indocyanine green (ICG) as a fluorescence imaging tracer in breast, non-small cell lung, or hepatocellular carcinoma-bearing mice [52]. The tracer showed fast clearance via the kidneys, while still providing tumor-to-background ratios of $4.0 \pm 0.2$ in low MUC1-expressing HepG2 tumor cells. Tumors could be clearly localized and delineated in all models.

The expression of MUC1 on the apical surface of normal glandular epithelial cells may reduce tumor-to-background contrast, thus, limiting the application of MUC1-targeting contrast agents [47]. Although most mAbs recognize MUC1 irrespective of its glycosylation pattern, several targeting moieties target a highly tumor-specific conformational MUC1 epitope induced through increased expression of truncated $\mathrm{O}$-glycans sTn and Tn. The under-glycosylated (u) MUC1 or (tumor-associated) TA-MUC1 epitope, which becomes expressed on the entire cell surface. Zhao et al. described a promising alternative for serum marker-based therapeutic response monitoring by developing the bimodal MR/fluorescence imaging probe MN-EPPT, which targets uMUC1 [45-48]. Using spontaneous, human uMUC1-expressing mouse models of breast and pancreatic cancer, uMUC1 expression was detected using MR and fluorescence imaging as early as ductal carcinoma in situ (DCIS) and pancreatic intraepithelial neoplasia (PanIN) lesions onward [46,47]. Tracer uptake decreased after treatment with chemotherapy, suggesting a decrease of uMUC1 expression [45-47]. Conversely, increased tracer uptake after chemotherapy was observed in unresponsive tumors, even before 
anatomical changes were present, indicating uMUC1 as a marker for in vivo imaging of in situ lesions and chemoresistance and/or tumor progression [45,47]. Meanwhile, positive TA-MUC1 expression has been shown in non-small cell lung, ovarian, breast, gastric, colorectal, liver, cervical, kidney, thyroid, and other (non-epithelial) cancers [164,165]. Administration of gatipotuzumab (previously known as PankoMab-GEX), a humanized mAb that binds TA-MUC1 in a Tn/TF-dependent manner, was found safe and was well-tolerated in patients with advanced carcinomas, suggesting a potential pan-carcinoma imaging application of the targeting moiety [166].

Alternatively, GGSK-1/30, which is a murine mAb specific for an alternative MUC1 glycoprotein epitope, was conjugated to ${ }^{89} \mathrm{Zr}$ and evaluated for combined PET/MRI imaging of breast cancer-bearing human MUC1-expressing transgenic mice [54]. At $72 \mathrm{~h}$ post-injection, administration of ${ }^{89} \mathrm{Zr}-\mathrm{GGSK}-1 / 30$ revealed high tracer tumor uptake with lower uptake in excreting organs and healthy mammary tissue, providing high-contrast tumor delineation. Considering its expression in $90 \%$ of breast tumors, including triple-negative breast carcinomas, GGSK-1/30 also seems a promising targeting moiety for pan-breast cancer detection [54].

\subsection{Imaging of MUC1/MUC5AC:PAM4-Based Systems}

The PAM4 mAb, which recognizes a carbohydrate-induced conformational epitope on MUC1 and MUC5AC, has been evaluated as a targeting vehicle for therapy and imaging of pancreatic cancer. PAM4 stained approximately $85 \%$ of pancreatic carcinomas, while reactivity with pancreatitis and healthy pancreatic tissue was, respectively, less than $25 \%$ and absent [167]. Moreover, the PAM4-epitope is abundantly expressed in PDAC precursor lesions, namely in intraductal papillary mucinous neoplasms and from earliest PanIN lesions (PanIN-1A) onward, suggesting a role for PAM4 in early pancreatic cancer detection [168].

Several studies evaluated PAM4-based contrast agents for $\gamma$-scintigraphy of PDAC. Cardillo et al. used bsPAM4 to pre-target Capan-1 pancreatic tumor cells, following administration of histamine-succinyl-glycine peptide haptens ${ }^{111}$ In-IMP-156 or ${ }^{99} \mathrm{~m}$ Tc-IMP-192, that were developed to interact with bsPAM4 [58]. Subcutaneous Capan-1 xenografts could be imaged as early as $0.5 \mathrm{~h}$ after peptide hapten administration. At $3 \mathrm{~h}$ post-injection, high tumor-to-blood ratios of $36.5 \pm 8.3$ and $9.9 \pm 5.2$ were achieved using ${ }^{111}$ In-IMP-156 and ${ }^{99} \mathrm{~m}$ Tc-IMP-192, respectively, which was significantly higher when compared to administration of direct-labeled bsPAM4 F( $\left.\mathrm{ab}^{\prime}\right)_{2}$. More recently, the same group developed the bispecific, trivalent mAb TF10, which consists of two PAM4-derived Fab' fragments and one $\mathrm{mAb}-679$-derived $\mathrm{Fab}^{\prime}$, enabling interaction with the radio-labeled hapten-peptide ${ }^{111} \mathrm{In}-\mathrm{IMP}-288$ [57]. At $3 \mathrm{~h}$ post-injection to Capan-1 tumor-bearing mice, a tumor-to-blood ratio of $915.2 \pm 404.3$ was observed (vs. $5.2 \pm 1.0$ using ${ }^{111}$ In-DOTA-PAM4 IgG at $24 \mathrm{~h}$ ), allowing clear delineation of small tumor lesions. These results clearly show the advantages of a pre-targeting regime that both demonstrate the feasibility of PAM4-based systems for molecular imaging of PDAC.

\subsection{Imaging of MUC16}

MUC16 has been preclinically evaluated as a target for PET imaging of ovarian tumors, using the mAb B43.13 (oregevomab) or derived fragments conjugated to radionuclides ${ }^{64} \mathrm{Cu}$ or ${ }^{89} \mathrm{Zr}$ [61-63]. In human OVCAR3 tumor-bearing mice, ${ }^{89} \mathrm{Zr}$-B43.13 provided higher TBRs when compared to ${ }^{18} \mathrm{~F}-\mathrm{FDG}$, which is the gold standard for PET imaging in ovarian cancer [62]. Moreover, the tracer showed uptake in adjacent lymph nodes, which correlated with the lymphatic spread of tumor cells. Since a one-day imaging protocol is more attractive in a clinical setting, the authors attempted using a faster-clearing $\mathrm{ScFV}$ fragment of B43.13 conjugated to ${ }^{18} \mathrm{~F}$ in the same in vivo model [63]. Unfortunately, only a modest OVCAR3 tumor uptake was observed. In addition, since mouse B43.13 has been administered to patients and was well tolerated despite human-anti-mouse responses based on serum analysis, clinical application of the tracer seems feasible [62,169]. 


\section{Targeting the Glycome: Opportunities and Challenges}

Glycan targeting may offer major advantages in relation to protein targeting. Firstly, tumor-associated glycans may be very suitable targets for both therapy and imaging, taking into account their often-low abundance or absence on normal tissues and very dense expression on a wide range of tumors (Figure 3a) [170,171]. Secondly, since glycans are expressed on the outermost layer of the cell surface, they are highly likely to be accessible by administrated targeting vehicles, in contrast to membrane-bound proteins, that may even be masked by glycans (Figure 3b). Thirdly, glycosylation changes may be more pronounced as a response to disease compared to changes in the proteome with atypically-expressed glycans potentially present on many glycoproteins, essentially amplifying their expression [172,173]. These characteristics provide major advantages for imaging of early cancer stages onward, but also for the employment as a serum biomarker for diagnosis, follow-up, monitoring of therapeutic response, or patient stratification, with CA19.9/sLe as the most illustrative example for monitoring of pancreatic cancer (Figure 3c) [171,174,175]. Most importantly, glycan-directed tracers target multiple tumor-associated proteins simultaneously and provide a broader tumor-targeting strategy than individual protein targeting (Figure 3d). Within this context, especially mucin-type O-glycan sTn poses a suitable pan-carcinoma glycotarget, given its high, tumor-specific expression on oncoprotein CD44 as well as MUC1, MUC2, MUC5AC, and MUC6 [84].

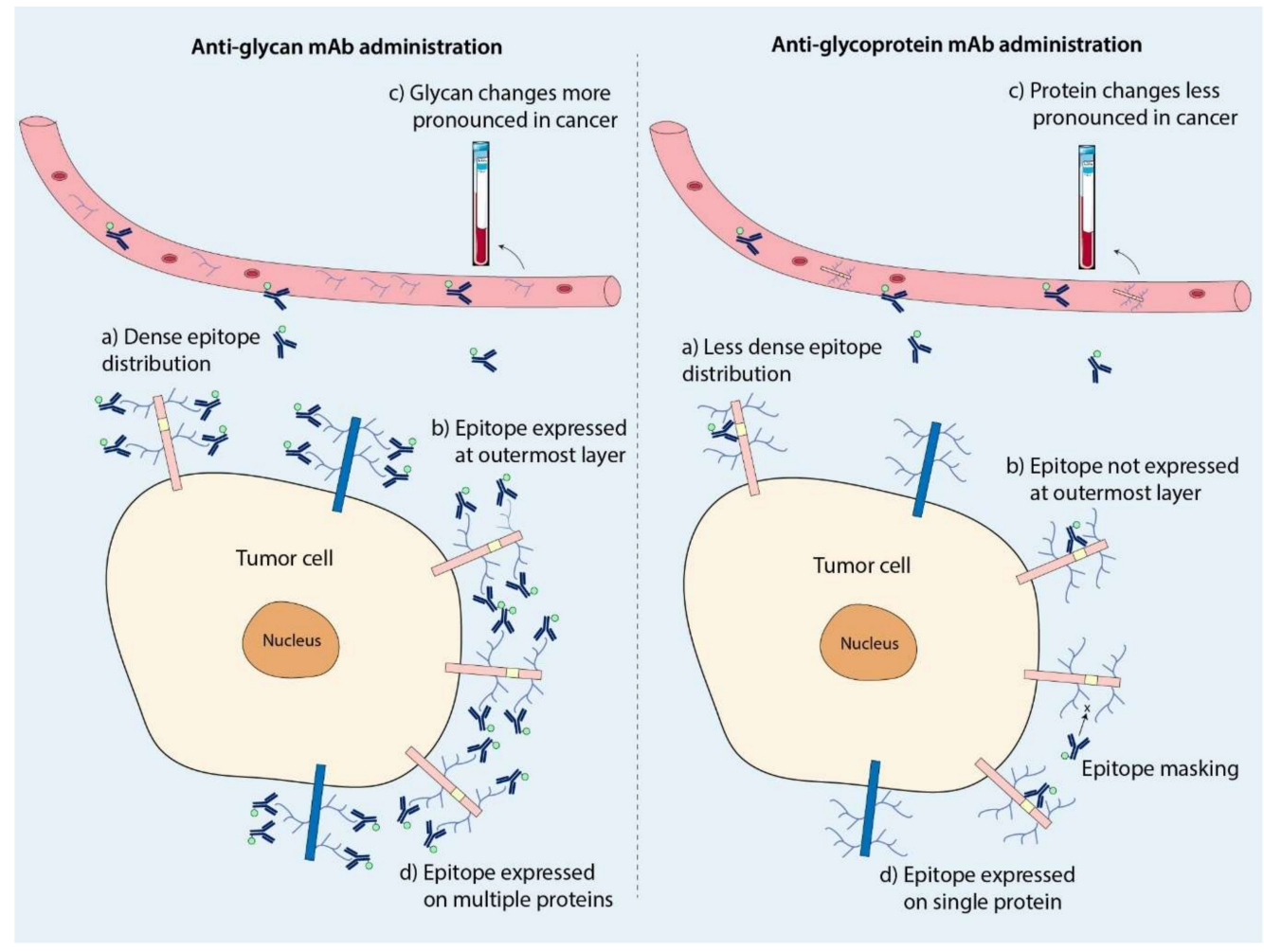

Figure 3. Schematic comparison of glycan-targeting versus traditional (glyco)protein targeting for molecular imaging of tumors. (a) Tumor-associated glycans (dark blue branches) are densely packed on multiple proteins (displayed in pink and dark blue) with higher density than binding epitopes on tumor-associated proteins (displayed in yellow). This may result in a denser accumulation of conjugated antibodies, subsequently enhancing tumor signal during imaging. (b) Glycans form the outer layer of proteins, making them easily accessible to administered targeting moieties. Noteworthily, glycans may mask binding domains on proteins, challenging specific binding of protein-directed targeting moieties. (c) Since aberrantly expressed glycans may be expressed on many glycoproteins (amplified expression), changes in glycoprotein glycosylation are more attractive for use as serum biomarkers than targeting of individual glycoproteins. (d) As similar tumor-associated glycan structures are expressed on multiple tumor-associated proteins, glycan-targeting can be more efficient compared to single protein targeting. 
Nevertheless, despite over 50 years of glycobiology, glycan-targeting seems still in its infancy. There may be several reasons for this, likely related to difficulties in anti-glycan mAb development [176]. Glycans are not very immunogenic, which results in a major disadvantage. Hybridoma-produced mAbs against glycans are often IgM pentamers that are less optimal, if not unsuitable, for in vivo targeting due to their low affinity and large size, essentially preventing extravasation [106,177-179]. Of note, several $\mathrm{N}$-glycans are intrinsically expressed by host species used in mAb production, which may explain low glycan immunogenicity. Thus, non-immunoglobin-derived targeting moieties, for which production is less dependent on sufficient immunogenicity, such as aptamers, lectins, and boronic acid derivatives, may represent promising alternatives to mAbs [176]. Alternatively, efforts have been made to improve glycan immunogenicity via various complex immunization protocols, with several successes [83,86]. In addition, the current lack of high-throughput screening methods, which are essential considering the extraordinarily high number of glycan structures, challenges the development of anti-glycan mAbs [176-180]. Since groups of glycans-and particularly $\mathrm{N}$-glycans-may be structurally highly related, mAbs are often promiscuous to a certain extent and may, thus, interact with multiple glyco-epitopes, which might be present on normal tissues [181,182]. $\mathrm{N}$-glycan targeting is, therefore, regularly overshadowed by the potential of $\mathrm{O}$-glycans. However, since novel techniques such as MALDI-TOF-MSI have recently improved $\mathrm{N}$-glycan detection and are estimated to increasingly contribute to the identification of novel tumor-specific $N$-glycans, the development of tracers targeting a very specific $N$-glycan structure seems feasible in the near future [183]. In fact, various studies have already indicated that several serum $N$-glycan profiles have extraordinarily high sensitivities and specificities for diagnosis of diverse cancer types [184-186]. Lastly, the translation of the results of preclinical glycan-based imaging studies to the human situation is often confounded. Since mice do not express fucosyltransferase-3, a major enzyme involved in Lewis glycan synthesis [187], and their glycome is, in various respects, not directly comparable to humans. This undoubtedly results in overestimation of TBR imaging contrast in studies evaluating these glycans as an imaging target. Therefore, the use of transgenic mice seems inevitable, but the same is true for virtually all protein-directed tracers.

\section{Conclusions}

The search for novel tumor-specific targets for targeted therapy and molecular imaging is an ever-continuing topic of research. Aberrant glycosylation of proteins and lipids as well as overexpression of mucins and proteoglycans is an increasingly relevant feature of cancer, providing tumor cells with unique attributes associated with disease progression. However, the perfect pan-carcinoma target may not exist. Tumor-associated glycans and heavily glycosylated proteins form a panel of targets that deserves extensive attention. As described here, glycan targeting, while remaining challenging, potentially offers major advantages over protein targeting for imaging and therapy. Several promising targeting moieties are currently available, of which some have been already evaluated for imaging and therapeutic purposes. In this review, we summarized the ongoing research within the field of glycan imaging and intended to provide a firm foundation for glycan-based improvement of cancer care in the near future.

Author Contributions: R.D.H. collected all relevant literature and wrote the first version of the manuscript. C.F.M.S. was a major contributor during manuscript editing. M.V., L.G.D., M.W., V.M.B., P.J.K.K., L.-F.d.G.-O. and A.L.V. all contributed to the final version. All authors have read and agreed to the published version of the manuscript.

Funding: This research received no external funding. C.F.M.S. was in part funded by the European Commission under Marie Sklodowska-Curie Action awards: H2020-MSCA-RISE-2017 (777682-CANCER), H2020-MSCA-ITN-2018 (813834-pHioniC), H2020-MSCA-ITN-2019 (857894-CAST), H2010-MSCA-ITN-2019 (861190-PAVE), and H2020-MSCA-RISE-2019 (872860-PRISAR2).

Conflicts of Interest: L.G.D. is CSO of Scancell Ltd. (the company that developed the FG88.2/CH88.2 and 692/29 $\mathrm{mAbs}$ ) and has ownership interest in Scancell Ltd. M.V. is an employee of Scancell Ltd. All remaining authors declare that they have no conflict of interest. 


\section{References}

1. Fass, L. Imaging and cancer: A review. Mol. Oncol. 2008, 2, 115-152. [CrossRef]

2. Weissleder, R. Molecular imaging in cancer. Science 2006, 312, 1168-1171. [CrossRef]

3. Frangioni, J.V. New technologies for human cancer imaging. J. Clin. Oncol. 2008, 26, 4012-4021. [CrossRef] [PubMed]

4. Munkley, J.; Elliott, D.J. Hallmarks of glycosylation in cancer. Oncotarget 2016, 7, 35478-35489. [CrossRef] [PubMed]

5. Wong, C.H. Protein glycosylation: New challenges and opportunities. J. Org. Chem. 2005, 70, 4219-4225. [CrossRef] [PubMed]

6. Varki, A.; Kornfeld, S. Historical background and overview. In Essentials of Glycobiology; Varki, A., Cummings, R.D., Esko, J.D., Stanley, P., Hart, G.W., Aebi, M., Darvill, A.G., Kinoshita, T., Packer, N.H., Prestegard, J.H., Eds.; Cold Spring Harbor Laboratory Press, Cold Spring Harbor: New York, NY, USA, 2015; pp. 1-18. [CrossRef]

7. Pinho, S.; Marcos, N.T.; Ferreira, B.; Carvalho, A.S.; Oliveira, M.J.; Santos-Silva, F.; Harduin-Lepers, A.; Reis, C.A. Biological significance of cancer-associated sialyl-Tn antigen: Modulation of malignant phenotype in gastric carcinoma cells. Cancer Lett. 2007, 249, 157-170. [CrossRef]

8. Munkley, J. The Role of Sialyl-Tn in Cancer. Int. J. Mol. Sci. 2016, 17, 275. [CrossRef] [PubMed]

9. Blanas, A.; Sahasrabudhe, N.M.; Rodríguez, E.; van Kooyk, Y.; van Vliet, S.J. Fucosylated antigens in cancer: An alliance toward tumor progression, metastasis, and resistance to chemotherapy. Front Oncol. 2018, 8, 39. [CrossRef]

10. Reily, C.; Stewart, T.J.; Renfrow, M.B.; Novak, J. Glycosylation in health and disease. Nat. Rev. Nephrol. 2019, 15, 346-366. [CrossRef]

11. Sakuma, S.; Yu, J.Y.; Quang, T.; Hiwatari, K.; Kumagai, H.; Kao, S.; Holt, A.; Erskind, J.; McClure, R.; Siuta, M.; et al. Fluorescence-based endoscopic imaging of Thomsen-Friedenreich antigen to improve early detection of colorectal cancer. Int. J. Cancer 2015, 136, 1095-1103. [CrossRef]

12. Kumar, S.R.; Gallazzi, F.A.; Quinn, T.P.; Deutscher, S.L. (64) Cu-labeled peptide for PET of breast carcinomas expressing the Thomsen-Friedenreich carbohydrate antigen. J. Nucl. Med. 2011, 52, 1819-1826. [CrossRef] [PubMed]

13. Coustets, M.; Ladurantie, C.; Bellard, E.; Prat, M.; Rols, M.P.; Ecochard, V.; Ferron, G.; Chabot, S.; Golzio, M.; Paquereau, L. Development of a near infrared protein nanoprobe targeting Thomsen-Friedenreich antigen for intraoperative detection of submillimeter nodules in an ovarian peritoneal carcinomatosis mouse model. Biomaterials 2020, 241, 119908. [CrossRef] [PubMed]

14. Danussi, C.; Coslovi, A.; Campa, C.; Mucignat, M.T.; Spessotto, P.; Uggeri, F.; Paoletti, S.; Colombatti, A. A newly generated functional antibody identifies Tn antigen as a novel determinant in the cancer cell-lymphatic endothelium interaction. Glycobiology 2009, 19, 1056-1067. [CrossRef] [PubMed]

15. Gong, L.; Ding, H.; Long, N.E.; Sullivan, B.J.; Martin, E.W., Jr.; Magliery, T.J.; Tweedle, M.F. A 3E8.scFv.Cys-IR800 conjugate targeting TAG-72 in an orthotopic colorectal cancer model. Mol. Imaging Biol. 2018, 20, 47-54. [CrossRef] [PubMed]

16. Zou, P.; Xu, S.; Povoski, S.P.; Wang, A.; Johnson, M.A.; Martin, E.W., Jr.; Subramaniam, V.; Xu, R.; Sun, D. Near-infrared fluorescence labeled anti-TAG-72 monoclonal antibodies for tumor imaging in colorectal cancer xenograft mice. Mol. Pharm. 2009, 6, 428-440. [CrossRef]

17. Zou, P.; Povoski, S.P.; Hall, N.C.; Carlton, M.M.; Hinkle, G.H.; Xu, R.X.; Mojzisik, C.M.; Johnson, M.A.; Knopp, M.V.; Martin, E.W., Jr.; et al. 124I-HuCC49deltaCH2 for TAG-72 antigen-directed positron emission tomography (PET) imaging of LS174T colon adenocarcinoma tumor implants in xenograft mice: Preliminary results. World J. Surg. Oncol. 2010, 8, 65. [CrossRef]

18. Knight, J.C.; Mosley, M.; Uyeda, H.T.; Cong, M.; Fan, F.; Faulkner, S.; Cornelissen, B. In vivo pretargeted imaging of HER2 and TAG-72 expression using the halotag enzyme. Mol. Pharm. 2017, 14, 2307-2313. [CrossRef]

19. Chinn, P.C.; Morena, R.A.; Santoro, D.A.; Kazules, T.; Kashmiri, S.V.; Schlom, J.; Hanna, N.; Braslawsky, G. Pharmacokinetics and tumor localization of (111) in-labeled HuCC49DeltaC(H)2 in BALB/c mice and athymic murine colon carcinoma xenograft. Cancer Biother. Radiopharm. 2006, 21, 106-116. [CrossRef] 
20. Rossin, R.; Läppchen, T.; van den Bosch, S.M.; Laforest, R.; Robillard, M.S. Diels-Alder reaction for tumor pretargeting: In vivo chemistry can boost tumor radiation dose compared with directly labeled antibody. J. Nucl. Med. 2013, 54, 1989-1995. [CrossRef]

21. Rossin, R.; van Duijnhoven, S.M.J.; Läppchen, T.; van den Bosch, S.M.; Robillard, M.S. Trans-cyclooctene tag with improved properties for tumor pretargeting with the Diels-Alder reaction. Mol. Pharm. 2014, 11, 3090-3096. [CrossRef]

22. Houvast, R.D.; Baart, V.M.; Bhairosingh, S.S.; Cordfunke, R.A.; Chua, J.X.; Vankemmelbeke, M.; Parsons, T.; Kuppen, P.J.K.; Durrant, L.G.; Vahrmeijer, A.L.; et al. Glycan-based near-infrared fluorescent (NIRF) imaging of gastrointestinal tumors: A preclinical proof-of-concept in vivo study. Mol. Imaging Biol. 2020. [CrossRef] [PubMed]

23. McElroy, M.; Kaushal, S.; Luiken, G.A.; Talamini, M.A.; Moossa, A.R.; Hoffman, R.M.; Bouvet, M. Imaging of primary and metastatic pancreatic cancer using a fluorophore-conjugated anti-CA19-9 antibody for surgical navigation. World J. Surg. 2008, 32, 1057-1066. [CrossRef] [PubMed]

24. Hiroshima, Y.; Maawy, A.; Zhang, Y.; Murakami, T.; Momiyama, M.; Mori, R.; Matsuyama, R.; Katz, M.H.; Fleming, J.B.; Chishima, T.; et al. Metastatic recurrence in a pancreatic cancer patient derived orthotopic xenograft (PDOX) nude mouse model is inhibited by neoadjuvant chemotherapy in combination with fluorescence-guided surgery with an anti-CA 19-9-conjugated fluorophore. PLoS ONE 2014, 9, e114310. [CrossRef] [PubMed]

25. Girgis, M.D.; Kenanova, V.; Olafsen, T.; McCabe, K.E.; Wu, A.M.; Tomlinson, J.S. Anti-CA19-9 diabody as a PET imaging probe for pancreas cancer. J. Surg. Res. 2011, 170, 169-178. [CrossRef] [PubMed]

26. Girgis, M.D.; Federman, N.; Rochefort, M.M.; McCabe, K.E.; Wu, A.M.; Nagy, J.O.; Denny, C.; Tomlinson, J.S. An engineered anti-CA19-9 cys-diabody for positron emission tomography imaging of pancreatic cancer and targeting of polymerized liposomal nanoparticles. J. Surg. Res. 2013, 185, 45-55. [CrossRef]

27. Escorcia, F.E.; Steckler, J.M.; Abdel-Atti, D.; Price, E.W.; Carlin, S.D.; Scholz, W.W.; Lewis, J.S.; Houghton, J.L.J.M.I. Biology. Tumor-specific Zr-89 immuno-PET imaging in a human bladder cancer model. Mol. Imaging Biol. 2018, 20, 808-815. [CrossRef]

28. Houghton, J.L.; Abdel-Atti, D.; Scholz, W.W.; Lewis, J.S. Preloading with unlabeled CA19.9 targeted human monoclonal antibody leads to improved PET imaging with 89Zr-5B1. Mol. Pharm. 2017, 14, 908-915. [CrossRef]

29. Houghton, J.L.; Zeglis, B.M.; Abdel-Atti, D.; Sawada, R.; Scholz, W.W.; Lewis, J.S. Pretargeted immuno-pet of pancreatic cancer: Overcoming circulating antigen and internalized antibody to reduce radiation doses. J. Nucl. Med. 2016, 57, 453-459. [CrossRef]

30. Rainey, J.; Maffuid, P.; Scholz, W.W.; Ostrowski, J.; Jun, H.T.; Resnick, P.; Li, X.; Bahn, J.D.; Zimmerman, S.; Chen, K.; et al. Abstract 3036: PEGylated hyaluronidase increases tumor uptake of 89Zr-DFO-HuMab-5B1 (MVT-2163) in a CA19-9 positive hyaluronan-accumulating pancreatic cancer model. Cancer Res. 2018, 78, 3036. [CrossRef]

31. Houghton, J.L.; Zeglis, B.M.; Abdel-Atti, D.; Aggeler, R.; Sawada, R.; Agnew, B.J.; Scholz, W.W.; Lewis, J.S. Site-specifically labeled CA19.9-targeted immunoconjugates for the PET, NIRF, and multimodal PET/NIRF imaging of pancreatic cancer. Proc. Natl. Acad. Sci. USA 2015, 112, 15850-15855. [CrossRef]

32. Hirai, M.; Minematsu, H.; Kondo, N.; Oie, K.; Igarashi, K.; Yamazaki, N. Accumulation of liposome with Sialyl Lewis $\mathrm{X}$ to inflammation and tumor region: Application to in vivo bio-imaging. Biochem. Biophys. Res. Commun. 2007, 353, 553-558. [CrossRef] [PubMed]

33. Lovqvist, A.; Humm, J.L.; Sheikh, A.; Finn, R.D.; Koziorowski, J.; Ruan, S.; Pentlow, K.S.; Jungbluth, A.; Welt, S.; Lee, F.T.; et al. PET imaging of (86) Y-labeled anti-Lewis Y monoclonal antibodies in a nude mouse model: Comparison between (86) Y and (111) in radiolabels. J. Nucl. Med. 2001, 42, 1281-1287. [PubMed]

34. Tahtis, K.; Lee, F.T.; Smyth, F.E.; Power, B.E.; Renner, C.; Brechbiel, M.W.; Old, L.J.; Hudson, P.J.; Scott, A.M. Biodistribution properties of (111) indium-labeled C-functionalized trans-cyclohexyl diethylenetriaminepentaacetic acid humanized $3 S 193$ diabody and $\mathrm{F}\left(\mathrm{ab}^{\prime}\right)(2)$ constructs in a breast carcinoma xenograft model. Clin. Cancer Res. 2001, 7, 1061-1072. [PubMed]

35. Wellens, L.M.; Deken, M.M.; Sier, C.F.M.; Johnson, H.R.; de la Jara Ortiz, F.; Bhairosingh, S.S.; Houvast, R.D.; Kholosy, W.M.; Baart, V.M.; Pieters, A.; et al. Anti-GD2-IRDye800CW as a targeted probe for fluorescence-guided surgery in neuroblastoma. Sci. Rep. 2020, 10, 17667. [CrossRef] 
36. Vavere, A.L.; Butch, E.R.; Dearling, J.L.; Packard, A.B.; Navid, F.; Shulkin, B.L.; Barfield, R.C.; Snyder, S.E. 64Cu-p-NH2-Bn-DOTA-hu14.18K322A, a PET radiotracer targeting neuroblastoma and melanoma. J. Nucl. Med. 2012, 53, 1772-1778. [CrossRef]

37. Butch, E.R.; Mead, P.E.; Amador Diaz, V.; Tillman, H.; Stewart, E.; Mishra, J.K.; Kim, J.; Bahrami, A.; Dearling, J.L.J.; Packard, A.B.; et al. Positron emission tomography detects in vivo expression of disialoganglioside GD2 in mouse models of primary and metastatic osteosarcoma. Cancer Res. 2019, 79, 3112-3124. [CrossRef]

38. Kimbrough, C.W.; Hudson, S.; Khanal, A.; Egger, M.E.; McNally, L.R. Orthotopic pancreatic tumors detected by optoacoustic tomography using Syndecan-1. J. Surg. Res. 2015, 193, 246-254. [CrossRef]

39. Bailly, C.; Gouard, S.; Lacombe, M.; Remaud-Le Saëc, P.; Chalopin, B.; Bourgeois, M.; Chouin, N.; Tripier, R.; Halime, Z.; Haddad, F.; et al. Comparison of Immuno-PET of CD138 and PET imaging with (64) $\mathrm{CuCl}(2)$ and (18)F-FDG in a preclinical syngeneic model of multiple myeloma. Oncotarget 2018, 9, 9061-9072. [CrossRef]

40. Huang, X.; Fan, C.; Zhu, H.; Le, W.; Cui, S.; Chen, X.; Li, W.; Zhang, F.; Huang, Y.; Sh, D.; et al. Glypican-1-antibody-conjugated Gd-Au nanoclusters for FI/MRI dual-modal targeted detection of pancreatic cancer. Int. J. Nanomed. 2018, 13, 2585-2599. [CrossRef]

41. Li, W.; Xiao, X.; Li, X.; Xu, Y.; Ma, L.; Guo, L.; Yan, C.; Wu, Y. Detecting GPC3-expressing hepatocellular carcinoma with $\mathrm{L} 5$ peptide-guided pretargeting approach: In vitro and in vivo MR imaging experiments. Contrast Media Mol. Imaging 2018, 2018, 5-13. [CrossRef]

42. Zhu, D.; Qin, Y.; Wang, J.; Zhang, L.; Zou, S.; Zhu, X.; Zhu, L. Novel glypican-3-binding peptide for in vivo hepatocellular carcinoma fluorescent imaging. Bioconjug. Chem. 2016, 27, 831-839. [CrossRef] [PubMed]

43. Sham, J.G.; Kievit, F.M.; Grierson, J.R.; Miyaoka, R.S.; Yeh, M.M.; Zhang, M.; Yeung, R.S.; Minoshima, S.; Park, J.O. Glypican-3-targeted 89Zr PET imaging of hepatocellular carcinoma. J. Nucl. Med. 2014, 55, 799-804. [CrossRef] [PubMed]

44. Sham, J.G.; Kievit, F.M.; Grierson, J.R.; Chiarelli, P.A.; Miyaoka, R.S.; Zhang, M.; Yeung, R.S.; Minoshima, S.; Park, J.O. Glypican-3-targeting F(ab')2 for 89Zr PET of hepatocellular carcinoma. J. Nucl. Med. 2014, 55, 2032-2037. [CrossRef] [PubMed]

45. Zhao, H.; Richardson, R.; Talebloo, N.; Mukherjee, P.; Wang, P.; Moore, A. uMUC1-targeting magnetic resonance imaging of therapeutic response in an orthotropic mouse model of colon cancer. Mol. Imag. Biol. 2019, 21, 852-860. [CrossRef]

46. Ghosh, S.K.; Uchida, M.; Yoo, B.; Ross, A.W.; Gendler, S.J.; Gong, J.; Moore, A.; Medarova, Z. Targeted imaging of breast tumor progression and therapeutic response in a human uMUC-1 expressing transgenic mouse model. Int. J. Cancer 2013, 132, 1860-1867. [CrossRef]

47. Wang, P.; Yoo, B.; Sherman, S.; Mukherjee, P.; Ross, A.; Pantazopoulos, P.; Petkova, V.; Farrar, C.; Medarova, Z.; Moore, A. Predictive imaging of chemotherapeutic response in a transgenic mouse model of pancreatic cancer. Int. J. Cancer 2016, 139, 712-718. [CrossRef]

48. Moore, A.; Medarova, Z.; Potthast, A.; Dai, G. In vivo targeting of underglycosylated MUC-1 tumor antigen using a multimodal imaging probe. Cancer Res. 2004, 64, 1821-1827. [CrossRef]

49. Park, J.Y.; Hiroshima, Y.; Lee, J.Y.; Maawy, A.A.; Hoffman, R.M.; Bouvet, M. MUC1 Selectively targets human pancreatic cancer in orthotopic nude mouse models. PLoS ONE 2015, 10, e0122100. [CrossRef]

50. Wu, G.; Maharjan, S.; Kim, D.; Kim, J.N.; Park, B.K.; Koh, H.; Moon, K.; Lee, Y.; Kwon, H.-J. A novel monoclonal antibody targets mucin1 and attenuates growth in pancreatic cancer model. Int. J. Mol. Sci. 2018, 19, 2004. [CrossRef]

51. Zhang, Q.; Wang, F.; Wu, Y.-S.; Zhang, K.-K.; Lin, Y.; Zhu, X.-Q.; Lv, J.-Q.; Lu, X.-S.; Zhang, X.-L.; Hu, Y.; et al. Dual-color labeled anti-mucin 1 antibody for imaging of ovarian cancer: A preliminary animal study. Oncol. Lett. 2015, 9, 1231-1235. [CrossRef]

52. Chen, H.; Zhao, J.; Zhang, M.; Yang, H.; Ma, Y.; Gu, Y. MUC1 aptamer-based near-infrared fluorescence probes for tumor imaging. Mol. Imaging Biol. 2015, 17, 38-48. [CrossRef] [PubMed]

53. Moore, L.J.; Roy, L.D.; Zhou, R.; Grover, P.; Wu, S.T.; Curry, J.M.; Dillon, L.M.; Puri, P.M.; Yazdanifar, M.; Puri, R.; et al. Antibody-guided in vivo imaging for early detection of mammary gland tumors. Transl. Oncol. 2016, 9, 295-305. [CrossRef] [PubMed] 
54. Stergiou, N.; Nagel, J.; Pektor, S.; Heimes, A.S.; Jäkel, J.; Brenner, W.; Schmidt, M.; Miederer, M.; Kunz, H.; Roesch, F.; et al. Evaluation of a novel monoclonal antibody against tumor-associated MUC1 for diagnosis and prognosis of breast cancer. Int. J. Med. Sci. 2019, 16, 1188-1198. [CrossRef] [PubMed]

55. Alirezapour, B.; Rasaee, M.J.; Jalilian, A.R.; Rajabifar, S.; Mohammadnejad, J.; Paknejad, M.; Maadi, E.; Moradkhani, S. Development of [(6)(4) Cu]-DOTA-PR81 radioimmunoconjugate for MUC-1 positive PET imaging. Nucl. Med. Biol. 2016, 43, 73-80. [CrossRef] [PubMed]

56. Salouti, M.; Rajabi, H.; Babaei, M.H.; Rasaee, M.J. Breast tumor targeting with (99 m) Tc-HYNIC-PR81 complex as a new biologic radiopharmaceutical. Nucl. Med. Biol. 2008, 35, 763-768. [CrossRef]

57. Gold, D.V.; Goldenberg, D.M.; Karacay, H.; Rossi, E.A.; Chang, C.-H.; Cardillo, T.M.; McBride, W.J.; Sharkey, R.M. A Novel bispecific, trivalent antibody construct for targeting pancreatic carcinoma. Cancer Res. 2008, 68, 4819-4826. [CrossRef]

58. Cardillo, T.M.; Karacay, H.; Goldenberg, D.M.; Yeldell, D.; Chang, C.-H.; Modrak, D.E.; Sharkey, R.M.; Gold, D.V. Improved targeting of pancreatic cancer. Clin. Cancer Res. 2004, 10, 3552. [CrossRef]

59. Rossez, Y.; Burtea, C.; Laurent, S.; Gosset, P.; Leonard, R.; Gonzalez, W.; Ballet, S.; Raynal, I.; Rousseaux, O.; Dugue, T.; et al. Early detection of colonic dysplasia by magnetic resonance molecular imaging with a contrast agent raised against the colon cancer marker MUC5AC. Control Med. Mol. Imaging 2016, 11, 211-221. [CrossRef]

60. Olson, M.T.; Wojtynek, N.E.; Talmon, G.A.; Caffrey, T.C.; Radhakrishnan, P.; Ly, Q.P.; Hollingsworth, M.A.; Mohs, A.M. Development of a MUC16-targeted near-infrared fluorescent antibody conjugate for intraoperative imaging of pancreatic cancer. Mol. Cancer Ther. 2020, 19, 1670-1681. [CrossRef]

61. Sharma, S.K.; Wuest, M.; Wang, M.; Glubrecht, D.; Andrais, B.; Lapi, S.E.; Wuest, F. Immuno-PET of epithelial ovarian cancer: Harnessing the potential of CA125 for non-invasive imaging. EJNMMI Res. 2015, 4, 60. [CrossRef]

62. Sharma, S.K.; Sevak, K.K.; Monette, S.; Carlin, S.D.; Knight, J.C.; Wuest, F.R.; Sala, E.; Zeglis, B.M.; Lewis, J.S. Preclinical 89Zr immuno-PET of high-grade serous ovarian cancer and lymph node metastasis. J. Nucl. Med. 2016, 57, 771-776. [CrossRef] [PubMed]

63. Sharma, S.K.; Wuest, M.; Way, J.D.; Bouvet, V.R.; Wang, M.; Wuest, F.R. Synthesis and pre-clinical evaluation of an (18) F-labeled single-chain antibody fragment for PET imaging of epithelial ovarian cancer. Am. J. Nucl. Med. Mol. Imaging 2016, 6, 185-198. [PubMed]

64. Cohen, A.M.; Martin, E.W., Jr.; Lavery, I.; Daly, J.; Sardi, A.; Aitken, D.; Bland, K.; Mojzisik, C.; Hinkle, G. Radioimmunoguided surgery using iodine 125 B72.3 in patients with colorectal cancer. Arch. Surg. 1991, 126, 349-352. [CrossRef] [PubMed]

65. Arnold, M.W.; Schneebaum, S.; Berens, A.; Petty, L.; Mojzisik, C.; Hinkle, G.; Martin, E.W., Jr. Intraoperative detection of colorectal cancer with radioimmunoguided surgery and CC49, a second-generation monoclonal antibody. Ann. Surg. 1992, 216, 627-632. [CrossRef] [PubMed]

66. Nag, S.; Martinez-Monge, R.; Nieroda, C.; Martin, E., Jr. Radioimmunoguided-intraoperative radiation therapy in colorectal carcinoma: A new technique to precisely define the clinical target volume. Int. J. Radiat. Oncol. Biol. Phys. 1999, 44, 133-137. [CrossRef]

67. Xiao, J.; Horst, S.; Hinkle, G.; Cao, X.; Kocak, E.; Fang, J.; Young, D.; Khazaeli, M.; Agnese, D.; Sun, D.; et al. Pharmacokinetics and clinical evaluation of 125I-radiolabeled humanized CC49 monoclonal antibody (HuCC49deltaC(H)2) in recurrent and metastatic colorectal cancer patients. Cancer Biother. Radiopharm. 2005, 20, 16-26. [CrossRef] [PubMed]

68. Fang, L.; Holford, N.H.G.; Hinkle, G.; Cao, X.; Xiao, J.J.; Bloomston, M.; Gibbs, S.; Al Saif, O.H.; Dalton, J.T.; Chan, K.K.; et al. Population pharmacokinetics of humanized monoclonal antibody HuCC49 $\Delta \mathrm{CH} 2$ and murine antibody CC49 in colorectal cancer patients. J. Clin. Pharm. 2007, 47, 227-237. [CrossRef]

69. Lohrmann, C.; O’Reilly, E.M.; O’Donoghue, J.A.; Pandit-Taskar, N.; Carrasquillo, J.A.; Lyashchenko, S.K.; Ruan, S.; Teng, R.; Scholz, W.; Maffuid, P.W.; et al. Retooling a blood-based biomarker: Phase I assessment of the high-affinity CA19-9 antibody HuMab-5B1 for immuno-PET imaging of pancreatic cancer. Clin. Cancer Res. 2019, 25, 7014-7023. [CrossRef]

70. Pai-Scherf, L.H.; Carrasquillo, J.A.; Paik, C.; Gansow, O.; Whatley, M.; Pearson, D.; Webber, K.; Hamilton, M.; Allegra, C.; Brechbiel, M.; et al. Imaging and phase I study of 111In- and 90Y-labeled anti-LewisY monoclonal antibody B3. Clin. Cancer Res. 2000, 6, 1720-1730. 
71. Quaia, E.; Krug, L.M.; Pandit-Taskar, N.; Nagel, A.; Reuter, V.E.; Humm, J.; Divgi, C. The value of gamma camera and computed tomography data set coregistration to assess Lewis $\mathrm{Y}$ antigen targeting in small cell lung cancer by (111) Indium-labeled humanized monoclonal antibody 3S193. Eur. J. Radiol. 2008, 67, 292-299. [CrossRef]

72. Reuland, P.; Geiger, L.; Thelen, M.H.; Handgretinger, R.; Haase, B.; Müller-Schauenburg, W.; Niethammer, D.; Bares, R. Follow-up in neuroblastoma: Comparison of metaiodobenzylguanidine and a chimeric anti-GD2 antibody for detection of tumor relapse and therapy response. J. Pediatr. Hematol. Oncol. 2001, 23, 437-442. [CrossRef] [PubMed]

73. Yeh, S.D.; Larson, S.M.; Burch, L.; Kushner, B.H.; Laquaglia, M.; Finn, R.; Cheung, N.K. Radioimmunodetection of neuroblastoma with iodine-131-3F8: Correlation with biopsy, iodine-131-metaiodobenzylguanidine and standard diagnostic modalities. J. Nucl. Med. 1991, 32, 769-776. [PubMed]

74. Larson, S.M.; Pentlow, K.S.; Volkow, N.D.; Wolf, A.P.; Finn, R.D.; Lambrecht, R.M.; Graham, M.C.; Di Resta, G.; Bendriem, B.; Daghighian, F.; et al. PET scanning of iodine-124-3F9 as an approach to tumor dosimetry during treatment planning for radioimmunotherapy in a child with neuroblastoma. J. Nucl. Med. 1992, 33, 2020-2023. [PubMed]

75. Hughes, O.; Perkins, A.; Frier, M.; Wastie, M.; Denton, G.; Price, M.; Denley, H.; Bishop, M. Imaging for staging bladder cancer: A clinical study of intravenous 111indium-labelled anti-MUC1 mucin monoclonal antibody C595. BJU Int. 2001, 87, 39-46. [CrossRef]

76. Simms, M.; Perkins, A.; Price, M.; Scholfield, D.; Bishop, M. 99mTechnetium-C595 radioimmunoscintigraphy: A potential staging tool for bladder cancer. BJU Int. 2001, 88, 686-691. [CrossRef]

77. Gulec, S.A.; Cohen, S.J.; Pennington, K.L.; Zuckier, L.S.; Hauke, R.J.; Horne, H.; Wegener, W.A.; Teoh, N.; Gold, D.V.; Sharkey, R.M.; et al. Treatment of advanced pancreatic carcinoma with 90Y-Clivatuzumab Tetraxetan: A phase I single-dose escalation trial. Clin. Cancer Res. 2011, 17, 4091-4100. [CrossRef]

78. Li, M.; Song, L.; Qin, X. Glycan changes: Cancer metastasis and anti-cancer vaccines. J. Biosci. 2010, 35, 665-673. [CrossRef]

79. Ohtsubo, K.; Marth, J.D. Glycosylation in cellular mechanisms of health and disease. Cell 2006, 126, 855-867. [CrossRef]

80. Varki, A. Biological roles of glycans. Glycobiology 2017, 27, 3-49. [CrossRef]

81. Brockhausen, I. Pathways of O-glycan biosynthesis in cancer cells. Biochim. Biophys. Acta 1999, 1473, 67-95. [CrossRef]

82. Vankemmelbeke, M.; Chua, J.X.; Durrant, L.G. Cancer cell associated glycans as targets for immunotherapy. Oncoimmunology 2016, 5, e1061177. [CrossRef] [PubMed]

83. Tivadar, S.T.; McIntosh, R.S.; Chua, J.X.; Moss, R.; Parsons, T.; Zaitoun, A.M.; Madhusudan, S.; Durrant, L.G.; Vankemmelbeke, M. Monoclonal antibody targeting sialyl-di-lewisa-Containing internalizing and non-internalizing glycoproteins with cancer immunotherapy development potential. Mol. Cancer Ther. 2019. [CrossRef]

84. Julien, S.; Videira, P.A.; Delannoy, P. Sialyl-tn in cancer: (how) did we miss the target? Biomolecules 2012, 2, 435-466. [CrossRef] [PubMed]

85. Trinchera, M.; Aronica, A.; Dall'Olio, F. Selectin ligands Sialyl-Lewis a and Sialyl-Lewis x in gastrointestinal cancers. Biology 2017, 6, 16. [CrossRef] [PubMed]

86. Prendergast, J.M.; Galvao da Silva, A.P.; Eavarone, D.A.; Ghaderi, D.; Zhang, M.; Brady, D.; Wicks, J.; DeSander, J.; Behrens, J.; Rueda, B.R. Novel anti-Sialyl-Tn monoclonal antibodies and antibody-drug conjugates demonstrate tumor specificity and anti-tumor activity. MAbs 2017, 9, 615-627. [CrossRef] [PubMed]

87. Eavarone, D.A.; Al-Alem, L.; Lugovskoy, A.; Prendergast, J.M.; Nazer, R.I.; Stein, J.N.; Dransfield, D.T.; Behrens, J.; Rueda, B.R. Humanized anti-Sialyl-Tn antibodies for the treatment of ovarian carcinoma. PLoS ONE 2018, 13, e0201314. [CrossRef]

88. Madjd, Z.; Parsons, T.; Watson, N.F.; Spendlove, I.; Ellis, I.; Durrant, L.G. High expression of Lewis y/b antigens is associated with decreased survival in lymph node negative breast carcinomas. Breast Cancer Res. 2005, 7, 780-787. [CrossRef]

89. Lottich, S.C.; Johnston, W.W.; Szpak, C.A.; Delong, E.R.; Thor, A.; Schlom, J. Tumor-associated antigen TAG-72: Correlation of expression in primary and metastatic breast carcinoma lesions. Breast Cancer Res. Treat 1985, 6, 49-56. [CrossRef] 
90. Loureiro, L.R.; Sousa, D.P.; Ferreira, D.; Chai, W.; Lima, L.; Pereira, C.; Lopes, C.B.; Correia, V.G.; Silva, L.M.; Li, C.; et al. Novel monoclonal antibody L2A5 specifically targeting sialyl-Tn and short glycans terminated by alpha-2-6 sialic acids. Sci. Rep. 2018, 8, 12196. [CrossRef]

91. Johnston, W.W.; Szpak, C.A.; Thor, A.; Schlom, J. Phenotypic characterization of lung cancers in fine needle aspiration biopsies using monoclonal antibody B72.3. Cancer Res. 1986, 46, 6462-6470.

92. Kadota, A.; Masutani, M.; Takei, M.; Horie, T. Evaluation of expression of CD15 and sCD15 in non-small cell lung cancer. Int. J. Oncol. 1999, 15, 1081-1089. [CrossRef]

93. Kajiwara, H.; Yasuda, M.; Kumaki, N.; Shibayama, T.; Osamura, Y. Expression of carbohydrate antigens (SSEA-1, sialyl-Lewis X, DU-PAN-2 and CA19-9) and E-selectin in urothelial carcinoma of the renal pelvis, ureter, and urinary bladder. Tokai J. Exp. Clin. Med. 2005, 30, 177-182. [PubMed]

94. Pochechueva, T.; Jacob, F.; Fedier, A.; Heinzelmann-Schwarz, V. Tumor-associated glycans and their role in gynecological cancers: Accelerating translational research by novel high-throughput approaches. Metabolites 2012, 2, 913-939. [CrossRef] [PubMed]

95. Contessa, J.N.; Bhojani, M.S.; Freeze, H.H.; Rehemtulla, A.; Lawrence, T.S. Inhibition of N-linked glycosylation disrupts receptor tyrosine kinase signaling in tumor cells. Cancer Res. 2008, 68, 3803-3809. [CrossRef] [PubMed]

96. Yue, T.; Maupin, K.A.; Fallon, B.; Li, L.; Partyka, K.; Anderson, M.A.; Brenner, D.E.; Kaul, K.; Zeh, H.; Moser, A.J.; et al. Enhanced discrimination of malignant from benign pancreatic disease by measuring the CA 19-9 antigen on specific protein carriers. PLoS ONE 2011, 6, e29180. [CrossRef] [PubMed]

97. Pinto, R.; Carvalho, A.S.; Conze, T.; Magalhães, A.; Picco, G.; Burchell, J.M.; Taylor-Papadimitriou, J.; Reis, C.A.; Almeida, R.; Mandel, U.; et al. Identification of new cancer biomarkers based on aberrant mucin glycoforms by in situ proximity ligation. J. Cell Mol. Med. 2012, 16, 1474-1484. [CrossRef] [PubMed]

98. Sarrats, A.; Saldova, R.; Pla, E.; Fort, E.; Harvey, D.J.; Struwe, W.B.; de Llorens, R.; Rudd, P.M.; Peracaula, R. Glycosylation of liver acute-phase proteins in pancreatic cancer and chronic pancreatitis. Proteomics Clin. Appl. 2010, 4, 432-448. [CrossRef] [PubMed]

99. Balmaña, M.; Sarrats, A.; Llop, E.; Barrabés, S.; Saldova, R.; Ferri, M.J.; Figueras, J.; Fort, E.; de Llorens, R.; Rudd, P.M.; et al. Identification of potential pancreatic cancer serum markers: Increased sialyl-Lewis $\mathrm{X}$ on ceruloplasmin. Clin. Chimica Acta 2015, 442, 56-62. [CrossRef]

100. Balmaña, M.; Duran, A.; Gomes, C.; Llop, E.; López-Martos, R.; Ortiz, M.R.; Barrabés, S.; Reis, C.A.; Peracaula, R. Analysis of sialyl-Lewis $x$ on MUC5AC and MUC1 mucins in pancreatic cancer tissues. Int. J. Biol. Macromol. 2018, 112, 33-45. [CrossRef]

101. Buffone, A.; Weaver, V.M. Don't sugarcoat it: How glycocalyx composition influences cancer progression. J. Cell Biol. 2020, 219. [CrossRef]

102. Burdick, M.D.; Harris, A.; Reid, C.J.; Iwamura, T.; Hollingsworth, M.A. Oligosaccharides expressed on MUC1 produced by pancreatic and colon tumor cell lines. J. Biol. Chem. 1997, 272, 24198-24202. [CrossRef] [PubMed]

103. Ozaki, H.; Matsuzaki, H.; Ando, H.; Kaji, H.; Nakanishi, H.; Ikehara, Y.; Narimatsu, H. Enhancement of metastatic ability by ectopic expression of ST6GalNAcI on a gastric cancer cell line in a mouse model. Clin. Exper. Metastasis 2012, 29, 229-238. [CrossRef] [PubMed]

104. Singh, R.; Campbell, B.J.; Yu, L.G.; Fernig, D.G.; Milton, J.D.; Goodlad, R.A.; FitzGerald, A.J.; Rhodes, J.M. Cell surface-expressed Thomsen-Friedenreich antigen in colon cancer is predominantly carried on high molecular weight splice variants of CD44. Glycobiology 2001, 11, 587-592. [CrossRef] [PubMed]

105. Loureiro, L.R.; Carrascal, M.A.; Barbas, A.; Ramalho, J.S.; Novo, C.; Delannoy, P.; Videira, P.A. Challenges in antibody development against Tn and Sialyl-Tn antigens. Biomolecules 2015, 5, 1783-1809. [CrossRef] [PubMed]

106. Rabu, C.; McIntosh, R.; Jurasova, Z.; Durrant, L. Glycans as targets for therapeutic antitumor antibodies. Future Oncol. 2012, 8, 943-960. [CrossRef] [PubMed]

107. Zhang, S.; Walberg, L.A.; Ogata, S.; Itzkowitz, S.H.; Koganty, R.R.; Reddish, M.; Gandhi, S.S.; Longenecker, B.M.; Lloyd, K.O.; Livingston, P.O. Immune sera and monoclonal antibodies define two configurations for the sialyl Tn tumor antigen. Cancer Res. 1995, 55, 3364-3368.

108. Sawada, R.; Sun, S.M.; Wu, X.; Hong, F.; Ragupathi, G.; Livingston, P.O.; Scholz, W.W. Human monoclonal antibodies to sialyl-Lewis (CA19.9) with potent CDC, ADCC, and antitumor activity. Clin. Cancer Res. 2011, 17, 1024-1032. [CrossRef] 
109. Ferreira, I.G.; Carrascal, M.; Mineiro, A.G.; Bugalho, A.; Borralho, P.; Silva, Z.; Dall'olio, F.; Videira, P.A. Carcinoembryonic antigen is a sialyl Lewis $x / a$ carrier and an E-selectin ligand in non-small cell lung cancer. Int. J. Oncol. 2019, 55, 1033-1048. [CrossRef] [PubMed]

110. Gomes, C.; Almeida, A.; Barreira, A.; Calheiros, J.; Pinto, F.; Abrantes, R.; Costa, A.; Polonia, A.; Campos, D.; Osório, H.; et al. Carcinoembryonic antigen carrying $\mathrm{SLe}(\mathrm{X})$ as a new biomarker of more aggressive gastric carcinomas. Theranostics 2019, 9, 7431-7446. [CrossRef] [PubMed]

111. Boogerd, L.S.F.; Hoogstins, C.E.S.; Schaap, D.P.; Kusters, M.; Handgraaf, H.J.M.; van der Valk, M.J.M.; Hilling, D.E.; Holman, F.A.; Peeters, K.; Mieog, J.S.D.; et al. Safety and effectiveness of SGM-101, a fluorescent antibody targeting carcinoembryonic antigen, for intraoperative detection of colorectal cancer: A dose-escalation pilot study. Lancet. Gastroenterol. Hepatol. 2018, 3, 181-191. [CrossRef]

112. Noble, P.; Spendlove, I.; Harding, S.; Parsons, T.; Durrant, L.G. Therapeutic targeting of Lewis(y) and Lewis(b) with a novel monoclonal antibody 692/29. PLoS ONE 2013, 8, e54892. [CrossRef] [PubMed]

113. Chua, J.X.; Vankemmelbeke, M.; McIntosh, R.S.; Clarke, P.A.; Moss, R.; Parsons, T.; Spendlove, I.; Zaitoun, A.M.; Madhusudan, S.; Durrant, L.G. Monoclonal antibodies targeting LecLex-related glycans with potent antitumor activity. Clin. Cancer Res. 2015, 21, 2963-2974. [CrossRef] [PubMed]

114. Shimomura, O.; Oda, T.; Tateno, H.; Ozawa, Y.; Kimura, S.; Sakashita, S.; Noguchi, M.; Hirabayashi, J.; Asashima, M.; Ohkohchi, N. A novel therapeutic strategy for pancreatic cancer: Targeting cell surface glycan using rBC2LC-N lectin-drug conjugate (LDC). Mol. Cancer Ther. 2018, 17, 183-195. [CrossRef] [PubMed]

115. Mishra, A.; Behura, A.; Mawatwal, S.; Kumar, A.; Naik, L.; Mohanty, S.S.; Manna, D.; Dokania, P.; Mishra, A.; Patra, S.K.; et al. Structure-function and application of plant lectins in disease biology and immunity. Food Chem. Toxicol. 2019, 134, 110827. [CrossRef] [PubMed]

116. Tiernan, J.P.; Ansari, I.; Hirst, N.A.; Millner, P.A.; Hughes, T.A.; Jayne, D.G. Intra-operative tumour detection and staging in colorectal cancer surgery. Colorectal Dis. 2012, 14, 510-520. [CrossRef]

117. Ohmi, Y.; Kambe, M.; Ohkawa, Y.; Hamamura, K.; Tajima, O.; Takeuchi, R.; Furukawa, K.; Furukawa, K. Differential roles of gangliosides in malignant properties of melanomas. PLoS ONE 2018, 13, e0206881. [CrossRef]

118. Marquina, G.; Waki, H.; Fernandez, L.E.; Kon, K.; Carr, A.; Valiente, O.; Perez, R.; Ando, S. Gangliosides expressed in human breast cancer. Cancer Res. 1996, 56, 5165-5171.

119. Kong, Y.; Yu, J.; Si, L.; Chi, Z.; Cui, C.; Sheng, X.; Guo, J. Abstract 2303: The expression of gangliosides GD2 is associated with worse prognosis in melanoma patients. Cancer Res. 2016, 76, 2303. [CrossRef]

120. Roth, M.; Linkowski, M.; Tarim, J.; Piperdi, S.; Sowers, R.; Geller, D.; Gill, J.; Gorlick, R. Ganglioside GD2 as a therapeutic target for antibody-mediated therapy in patients with osteosarcoma. Cancer 2014, 120, 548-554. [CrossRef]

121. Schulz, G.; Cheresh, D.A.; Varki, N.M.; Yu, A.; Staffileno, L.K.; Reisfeld, R.A. Detection of ganglioside GD2 in tumor tissues and sera of neuroblastoma patients. Cancer Res. 1984, 44, 5914-5920.

122. Alessandri, G.; Filippeschi, S.; Sinibaldi, P.; Mornet, F.; Passera, P.; Spreafico, F.; Cappa, P.M.; Gullino, P.M. Influence of gangliosides on primary and metastatic neoplastic growth in human and murine cells. Cancer Res. 1987, 47, 4243-4247. [PubMed]

123. Sarkar, T.R.; Battula, V.L.; Werden, S.J.; Vijay, G.V.; Ramirez-Peña, E.Q.; Taube, J.H.; Chang, J.T.; Miura, N.; Porter, W.; Sphyris, N.; et al. GD3 Synthase regulates epithelial-mesenchymal transition and metastasis in breast cancer. Oncogene 2015, 34, 2958-2967. [CrossRef] [PubMed]

124. Ploessl, C.; Pan, A.; Maples, K.T.; Lowe, D.K. Dinutuximab: An anti-GD2 monoclonal antibody for high-risk neuroblastoma. Ann. Pharmacother. 2016, 50, 416-422. [CrossRef] [PubMed]

125. Sait, S.; Modak, S. Anti-GD2 immunotherapy for neuroblastoma. Expert Rev. Anticancer Ther. 2017, 17, 889-904. [CrossRef] [PubMed]

126. Jiao, P.; Otto, M.; Geng, Q.; Li, C.; Li, F.; Butch, E.R.; Snyder, S.E.; Zhou, H.; Yan, B. Enhancing both CT imaging and natural killer cell-mediated cancer cell killing by a GD2-targeting nanoconstruct. J. Mater. Chem. B 2016, 4, 513-520. [CrossRef] [PubMed]

127. Massaad, C.A.; Zhang, G.; Pillai, L.; Azhdarinia, A.; Liu, W.; Sheikh, K.A. Fluorescently-tagged antiganglioside antibody selectively identifies peripheral nerve in living animals. Sci. Rep. 2015, 5, 15766. [CrossRef]

128. Yanagishita, M. Function of proteoglycans in the extracellular matrix. Acta Pathol. Jpn. 1993, 43, 283-293. [CrossRef] 
129. Elfenbein, A.; Simons, M. Auxiliary and autonomous proteoglycan signaling networks. Methods Enzymol. 2010, 480, 3-31. [CrossRef]

130. Wang, S.; Qiu, Y.; Bai, B. The expression, regulation, and biomarker potential of glypican-1 in cancer. Front Oncol. 2019, 9, 614. [CrossRef]

131. Nikitovic, D.; Berdiaki, A.; Spyridaki, I.; Krasanakis, T.; Tsatsakis, A.; Tzanakakis, G.N. Proteoglycans-biomarkers and targets in cancer therapy. Front Endocrinol. (Lausanne) 2018, 9, 69. [CrossRef]

132. Fico, A.; Maina, F.; Dono, R. Fine-tuning of cell signaling by glypicans. Cell Mol. Life Sci. 2011, 68, 923-929. [CrossRef] [PubMed]

133. Filmus, J.; Capurro, M. The role of glypicans in Hedgehog signaling. Matrix Biol. 2014, 35, $248-252$. [CrossRef] [PubMed]

134. Matsuo, I.; Kimura-Yoshida, C. Extracellular distribution of diffusible growth factors controlled by heparan sulfate proteoglycans during mammalian embryogenesis. Philos. Trans. R. Soc. Lond. B Biol. Sci. 2014, 369. [CrossRef] [PubMed]

135. Nagarajan, A.; Malvi, P.; Wajapeyee, N. Heparan sulfate and heparan sulfate proteoglycans in cancer initiation and progression. Front Endocrinol. (Lausanne) 2018, 9, 483. [CrossRef]

136. Sanderson, R.D.; Yang, Y.; Purushothaman, A.; Khotskaya, Y.B.; Ritchie, J.P.; Ramani, V.C. Proteoglycans and cancer. In Cell-Extracellular Matrix Interactions in Cancer; Zent, R., Pozzi, A., Eds.; Springer: New York, NY, USA, 2010; pp. 191-215. [CrossRef]

137. Nishida, T.; Kataoka, H. Glypican 3-targeted therapy in hepatocellular carcinoma. Cancers 2019, 11, 1339. [CrossRef]

138. Szatmari, T.; Otvos, R.; Hjerpe, A.; Dobra, K. Syndecan-1 in cancer: Implications for cell signaling, differentiation, and prognostication. Dis. Markers 2015, 2015, 796052. [CrossRef]

139. Liu, H.; Li, P.; Zhai, Y.; Qu, C.F.; Zhang, L.J.; Tan, Y.F.; Li, N.; Ding, H.G. Diagnostic value of glypican-3 in serum and liver for primary hepatocellular carcinoma. World J. Gastroenterol. 2010, 16, 4410-4415. [CrossRef]

140. Capurro, M.; Wanless, I.R.; Sherman, M.; Deboer, G.; Shi, W.; Miyoshi, E.; Filmus, J. Glypican-3: A novel serum and histochemical marker for hepatocellular carcinoma. Gastroenterology 2003, 125, 89-97. [CrossRef]

141. Libbrecht, L.; Severi, T.; Cassiman, D.; Vander Borght, S.; Pirenne, J.; Nevens, F.; Verslype, C.; van Pelt, J.; Roskams, T. Glypican-3 expression distinguishes small hepatocellular carcinomas from cirrhosis, dysplastic nodules, and focal nodular hyperplasia-like nodules. Am. J. Surg. Pathol. 2006, 30, 1405-1411. [CrossRef]

142. Di Paola, M.; Quarta, A.; Conversano, F.; Sbenaglia, E.A.; Bettini, S.; Valli, L.; Gigli, G.; Casciaro, S. Human hepatocarcinoma cell targeting by glypican-3 ligand peptide functionalized silica nanoparticles: Implications for ultrasound molecular imaging. Langmuir 2017, 33, 4490-4499. [CrossRef]

143. Shimizu, Y.; Suzuki, T.; Yoshikawa, T.; Endo, I.; Nakatsura, T. Next-Generation Cancer Immunotherapy Targeting Glypican-3. Front Oncol. 2019, 9, 248. [CrossRef] [PubMed]

144. Kufe, D.W.J.N.R.C. Mucins in cancer: Function, prognosis and therapy. Nat. Rev. Cancer 2009, 9, $874-885$. [CrossRef] [PubMed]

145. Nath, S.; Mukherjee, P. MUC1: A multifaceted oncoprotein with a key role in cancer progression. Trends Mol. Med. 2014, 20, 332-342. [CrossRef] [PubMed]

146. Kaur, S.; Kumar, S.; Momi, N.; Sasson, A.R.; Batra, S.K. Mucins in pancreatic cancer and its microenvironment. Nat. Rev. Gastroenterol. Hepatol. 2013, 10, 607-620. [CrossRef]

147. Tréhoux, S.; Duchêne, B.; Jonckheere, N.; Van Seuningen, I. The MUC1 oncomucin regulates pancreatic cancer cell biological properties and chemoresistance. Implication of p42-44 MAPK, Akt, Bcl-2 and MMP13 pathways. Biochem. Biophys. Res. Commun. 2015, 456, 757-762. [CrossRef]

148. Zhou, R.; Curry, J.M.; Roy, L.D.; Grover, P.; Haider, J.; Moore, L.J.; Wu, S.T.; Kamesh, A.; Yazdanifar, M.; Ahrens, W.A.; et al. A novel association of neuropilin-1 and MUC1 in pancreatic ductal adenocarcinoma: Role in induction of VEGF signaling and angiogenesis. Oncogene 2016, 35, 5608-5618. [CrossRef]

149. Sahraei, M.; Roy, L.D.; Curry, J.M.; Teresa, T.L.; Nath, S.; Besmer, D.; Kidiyoor, A.; Dalia, R.; Gendler, S.J.; Mukherjee, P. MUC1 regulates PDGFA expression during pancreatic cancer progression. Oncogene 2012, 31, 4935. [CrossRef] 
150. Grover, P.; Nath, S.; Nye, M.D.; Zhou, R.; Ahmad, M.; Mukherjee, P. SMAD4-independent activation of TGF- $\beta$ signaling by MUC1 in a human pancreatic cancer cell line. Oncotarget 2018, 9, 6897-6910. [CrossRef]

151. Muniyan, S.; Haridas, D.; Chugh, S.; Rachagani, S.; Lakshmanan, I.; Gupta, S.; Seshacharyulu, P.; Smith, L.M.; Ponnusamy, M.P.; Batra, S.K. MUC16 contributes to the metastasis of pancreatic ductal adenocarcinoma through focal adhesion mediated signaling mechanism. Genes Cancer 2016, 7, 110-124. [CrossRef]

152. Inaguma, S.; Kasai, K.; Ikeda, H. GLI1 facilitates the migration and invasion of pancreatic cancer cells through MUC5AC-mediated attenuation of E-cadherin. Oncogene 2010, 30, 714. [CrossRef]

153. Lakshmanan, I.; Ponnusamy, M.P.; Das, S.; Chakraborty, S.; Haridas, D.; Mukhopadhyay, P.; Lele, S.M.; Batra, S.K. MUC16 induced rapid G2/M transition via interactions with JAK2 for increased proliferation and anti-apoptosis in breast cancer cells. Oncogene 2012, 31, 805-817. [CrossRef]

154. Awaya, H.; Takeshima, Y.; Yamasaki, M.; Inai, K. Expression of MUC1, MUC2, MUC5AC, and MUC6 in atypical adenomatous hyperplasia, bronchioloalveolar carcinoma, adenocarcinoma with mixed subtypes, and mucinous bronchioloalveolar carcinoma of the lung. Am. J. Clin. Pathol. 2004, 121, 644-653. [CrossRef] [PubMed]

155. Situ, D.; Wang, J.; Ma, Y.; Zhu, Z.; Hu, Y.; Long, H.; Rong, T. Expression and prognostic relevance of MUC1 in stage IB non-small cell lung cancer. Med. Oncol. 2011, 28, 596-604. [CrossRef] [PubMed]

156. Hinoda, Y.; Ikematsu, Y.; Horinochi, M.; Sato, S.; Yamamoto, K.; Nakano, T.; Fukui, M.; Suehiro, Y.; Hamanaka, Y.; Nishikawa, Y.; et al. Increased expression of MUC1 in advanced pancreatic cancer. J. Gastroenterol. 2003, 38, 1162-1166. [CrossRef] [PubMed]

157. Streppel, M.M.; Vincent, A.; Mukherjee, R.; Campbell, N.R.; Chen, S.H.; Konstantopoulos, K.; Goggins, M.G.; Van Seuningen, I.; Maitra, A.; Montgomery, E.A. Mucin 16 (cancer antigen 125) expression in human tissues and cell lines and correlation with clinical outcome in adenocarcinomas of the pancreas, esophagus, stomach, and colon. Hum. Pathol. 2012, 43, 1755-1763. [CrossRef] [PubMed]

158. Rabassa, M.E.; Croce, M.V.; Pereyra, A.; Segal-Eiras, A. MUC1 expression and anti-MUC1 serum immune response in head and neck squamous cell carcinoma (HNSCC): A multivariate analysis. BMC Cancer 2006, 6, 253. [CrossRef]

159. Kannan, A.; Hertweck, K.L.; Philley, J.V.; Wells, R.B.; Dasgupta, S. Genetic Mutation and exosome signature of human papilloma virus associated oropharyngeal cancer. Sci. Rep. 2017, 7, 46102. [CrossRef]

160. Sato, S.; Kato, T.; Abe, K.; Hanaoka, T.; Yano, Y.; Kurosaki, A.; Yasuda, M.; Sekino, T.; Fujiwara, K.; Hasegawa, K. Pre-operative evaluation of circulating KL-6 levels as a biomarker for epithelial ovarian carcinoma and its correlation with tumor MUC1 expression. Oncol. Lett. 2017, 14, 776-786. [CrossRef]

161. Peters, I.T.; Hilders, C.G.; Sier, C.F.; Vahrmeijer, A.L.; Smit, V.T.; Baptist Trimbos, J.; Kuppen, P.J. Identification of cell-surface markers for detecting breast cancer cells in ovarian tissue. Arch. Gynecol. Obstet. 2016, 294, 385-393. [CrossRef]

162. Heublein, S.; Friese, K.; Kost, B.; Marmé, F.; Kuhn, C.; Mahner, S.; Dannecker, C.; Mayr, D.; Jeschke, U.; Vattai, A. TA-MUC1 as detected by the fully humanized, therapeutic antibody Gatipotzumab predicts poor prognosis in cervical cancer. J. Cancer Res. Clin. Oncol. 2018, 144, 1899-1907. [CrossRef]

163. Ginath, S.; Menczer, J.; Fintsi, Y.; Ben-Shem, E.; Glezerman, M.; Avinoach, I. Tissue and serum CA125 expression in endometrial cancer. Int. J. Gynecol. Cancer. 2002, 12, 372-375. [CrossRef] [PubMed]

164. Fan, X.N.; Karsten, U.; Goletz, S.; Cao, Y. Reactivity of a humanized antibody (hPankoMab) towards a tumor-related MUC1 epitope (TA-MUC1) with various human carcinomas. Pathol. Res. Pract. 2010, 206, 585-589. [CrossRef] [PubMed]

165. Dian, D.; Lenhard, M.; Mayr, D.; Heublein, S.; Karsten, U.; Goletz, S.; Kuhn, C.; Wiest, I.; Friese, K.; Weissenbacher, T.; et al. Staining of MUC1 in ovarian cancer tissues with PankoMab-GEX detecting the tumour-associated epitope, TA-MUC1, as compared to antibodies HMFG-1 and 115D8. Histol. Histopathol. 2013, 28, 239-244. [CrossRef] [PubMed]

166. Fiedler, W.; DeDosso, S.; Cresta, S.; Weidmann, J.; Tessari, A.; Salzberg, M.; Dietrich, B.; Baumeister, H.; Goletz, S.; Gianni, L.; et al. A phase I study of PankoMab-GEX, a humanised glyco-optimised monoclonal antibody to a novel tumour-specific MUC1 glycopeptide epitope in patients with advanced carcinomas. Eur. J. Cancer 2016, 63, 55-63. [CrossRef] [PubMed] 
167. Gold, D.V.; Lew, K.; Maliniak, R.; Hernandez, M.; Cardillo, T. Characterization of monoclonal antibody PAM4 reactive with a pancreatic cancer mucin. Int. J. Cancer 1994, 57, 204-210. [CrossRef]

168. Gold, D.V.; Karanjawala, Z.; Modrak, D.E.; Goldenberg, D.M.; Hruban, R.H. PAM4-reactive MUC1 is a biomarker for early pancreatic adenocarcinoma. Clin. Cancer Res. 2007, 13, 7380-7387. [CrossRef]

169. Berek, J.S.; Taylor, P.T.; Gordon, A.; Cunningham, M.J.; Finkler, N.; Orr, J., Jr.; Rivkin, S.; Schultes, B.C.; Whiteside, T.L.; Nicodemus, C.F. Randomized, placebo-controlled study of oregovomab for consolidation of clinical remission in patients with advanced ovarian cancer. J. Clin. Oncol. 2004, 22, 3507-3516. [CrossRef]

170. Kudelka, M.R.; Ju, T.; Heimburg-Molinaro, J.; Cummings, R.D. Simple sugars to complex disease-mucin-type O-glycans in cancer. Adv. Cancer Res. 2015, 126, 53-135. [CrossRef]

171. Stowell, S.R.; Ju, T.; Cummings, R.D. Protein glycosylation in cancer. Annu. Rev. Pathol. 2015, 10, 473-510. [CrossRef]

172. Fuster, M.M.; Esko, J.D. The sweet and sour of cancer: Glycans as novel therapeutic targets. Nat. Rev. Cancer 2005, 5, 526-542. [CrossRef]

173. Lebrilla, C.B.; An, H.J. The prospects of glycan biomarkers for the diagnosis of diseases. Mol. Biosyst. 2009, 5, 17-20. [CrossRef] [PubMed]

174. Tang, H.; Singh, S.; Partyka, K.; Kletter, D.; Hsueh, P.; Yadav, J.; Ensink, E.; Bern, M.; Hostetter, G.; Hartman, D.; et al. Glycan motif profiling reveals plasma sialyl-lewis x elevations in pancreatic cancers that are negative for sialyl-lewis A. Mol. Cell Proteomics 2015, 14, 1323-1333. [CrossRef] [PubMed]

175. Tang, Y.; Cui, Y.; Zhang, S.; Zhang, L. Chapter five-The sensitivity and specificity of serum glycan-based biomarkers for cancer detection. Prog. Mol. Biol. Transl. Sci. 2019, 162, 121-140. [CrossRef] [PubMed]

176. Tommasone, S.; Allabush, F.; Tagger, Y.K.; Norman, J.; Köpf, M.; Tucker, J.H.R.; Mendes, P.M. The challenges of glycan recognition with natural and artificial receptors. Chem. Soc. Rev. 2019, 48, 5488-5505. [CrossRef] [PubMed]

177. Adams, G.P.; Weiner, L.M. Monoclonal antibody therapy of cancer. Nat. Biotechn. 2005, 23, 1147-1157. [CrossRef]

178. Eisen, H.N. Affinity enhancement of antibodies: How low-affinity antibodies produced early in immune responses are followed by high-affinity antibodies later and in memory B-cell responses. Cancer Immunol. Res. 2014, 2, 381-392. [CrossRef]

179. Cao, Y.; Lan, Y.; Qian, J.; Zheng, Y.; Hong, S.; Li, H.; Wang, M.; Kwak, L.W.; Lin, D.; Yang, J.; et al. Targeting cell surface $\beta 2$-microglobulin by pentameric IgM antibodies. Br. J. Haematol. 2011, 154, 111-121. [CrossRef]

180. Manimala, J.C.; Roach, T.A.; Li, Z.; Gildersleeve, J.C. High-throughput carbohydrate microarray profiling of 27 antibodies demonstrates widespread specificity problems. Glycobiology 2007, 17, 17-23. [CrossRef]

181. Sterner, E.; Flanagan, N.; Gildersleeve, J.C. Perspectives on anti-glycan antibodies gleaned from development of a community resource database. ACS Chem. Biol. 2016, 11, 1773-1783. [CrossRef]

182. Cummings, R.D.; Darvill, A.G.; Etzler, M.E.; Hahn, M.G. Glycan-recognizing probes as tools. In Essentials of Glycobiology; Varki, A., Cummings, R.D., Esko, J.D., Stanley, P., Hart, G.W., Aebi, M., Darvill, A.G., Kinoshita, T., Packer, N.H., Prestegard, J.H., Eds.; Cold Spring Harbor Laboratory Press, Cold Spring Harbor: New York, NY, USA, 2015; pp. 611-625. [CrossRef]

183. Heijs, B.; Holst-Bernal, S.; de Graaff, M.A.; Briaire-de Bruijn, I.H.; Rodriguez-Girondo, M.; van de Sande, M.A.J.; Wuhrer, M.; McDonnell, L.A.; Bovée, J. Molecular signatures of tumor progression in myxoid liposarcoma identified by $\mathrm{N}$-glycan mass spectrometry imaging. Lab. Invest. 2020. [CrossRef]

184. Liu, Y.; Wang, C.; Wang, R.; Wu, Y.; Zhang, L.; Liu, B.F.; Cheng, L.; Liu, X. Isomer-specific profiling of $\mathrm{N}$-glycans derived from human serum for potential biomarker discovery in pancreatic cancer. J. Proteomics 2018, 181, 160-169. [CrossRef] [PubMed]

185. Gebrehiwot, A.G.; Melka, D.S.; Kassaye, Y.M.; Gemechu, T.; Lako, W.; Hinou, H.; Nishimura, S.-I. Exploring serum and immunoglobulin $\mathrm{G} \mathrm{N-glycome} \mathrm{as} \mathrm{diagnostic} \mathrm{biomarkers} \mathrm{for} \mathrm{early} \mathrm{detection} \mathrm{of}$ breast cancer in Ethiopian women. BMC Cancer 2019, 19, 588. [CrossRef] [PubMed]

186. Oikawa, M.; Hatakeyama, S.; Yoneyma, T.; Tobisawa, Y.; Narita, T.; Yamamoto, H.; Hashimoto, Y.; Koie, T.; Narita, S.; Sasaki, A.; et al. Significance of serum N-glycan profiling as a diagnostic biomarker in urothelial carcinoma. Eur. Urol. Focus 2018, 4, 405-411. [CrossRef] [PubMed] 
187. Gersten, K.M.; Natsuka, S.; Trinchera, M.; Petryniak, B.; Kelly, R.J.; Hiraiwa, N.; Jenkins, N.A.; Gilbert, D.J.; Copeland, N.G.; Lowe, J.B. Molecular cloning, expression, chromosomal assignment, and tissue-specific expression of a murine alpha-(1,3)-fucosyltransferase locus corresponding to the human ELAM-1 ligand fucosyl transferase. J. Biol. Chem. 1995, 270, 25047-25056. [CrossRef] [PubMed]

Publisher's Note: MDPI stays neutral with regard to jurisdictional claims in published maps and institutional affiliations.

(C) 2020 by the authors. Licensee MDPI, Basel, Switzerland. This article is an open access article distributed under the terms and conditions of the Creative Commons Attribution (CC BY) license (http://creativecommons.org/licenses/by/4.0/). 